\title{
The Perfectionisms of John Rawls
}

\author{
Steve Sheppard
}

\author{
The acts of even the gods \\ Have ends beyond their intent.
}

John Rawls stands in a small pantheon of writers whose ideas have shaped the vocabularies of their age. Like a classical deity, his work has been invoked by disciple and dissenter alike as the essential totem of the modem liberal state. But his Promethean creation has grown independent from its original design, attaining significance not only for its initial merits but also for the competition it offers to the plan of its creator.' So from the stage of Rawlsian Iiberal neutrality stalks the idea of legal perfectionism. ${ }^{2}$

Legal perfectionism is the doctrine according to which officials may adopt and enforce laws according to the officials' understanding of a good life, with the intended practical effect that people governed by such laws will lead better lives."

This article is derived from a supervision paper written for H.L.A. Hart in 1990; his criticism and encouragement gave it much of what strength it has. Conversations with numeruus friends and colleagues informed the development of this piecr, particularly Ronald Burr, Michand L. Corrado, Stcphen Davies, Barry and Bonny Dubner, Ronald Dworkin, Strefan Fauble, John Finnis, Kent Greenawalt, Mark Kende, James Penner, Joseph Raz, Kevin Saunders, Jeremy Shearmur, Pierre Sehlag. Evans Thomas, and Lenore Thomas. Portions of it were first dafted while a 1990 summer resident at the Institute for Humane Studies and while a John M. Olin Seholar in the United Kingdom in 1990 and 1991.

1. This adaptability may be essential to Rawls's works being perecived as classic texts by future generations. See Jacques Barzun, "Of What Use the Classies Today" in Morris Philipson, ed. The Forgotten Conditions of Teaching and Leaming (Chicago: Uniwersity of Chicago Pros, 1991) 133 at 134.45 . Thus, that Rawls's writing has antracted not only criticism but also interptetntion beyond his original designs may suggest that his witings will achieve the intellectual consonance of a classic. See Conal Condren, The Sratus and Appraisal of Classic Texts (Princeton. NJ: Princeton University Press, 1985) at 58, c. 8 and 9.

2. Legal perfectionism has become a growth industry in legal theory. A partial bibliography must include the recent wealth of scholarship with specific concerns, both supportive and contradictory. for the development of perfectionist theory. Certain pieces relied upon in the angument below include the following: David Norion, "Rawls" Theorn' of Jusfice: A 'Perfectionist' Rejoinder" (1973) 83 Ethics 50, 56 [heneinafter Norton, "A Perfectionist Rejoinder"]; T.M. Seanion. "Rawls" A Theory of Justice" in Noman Daniels, ed, Reading Raw'ls (Oxford: Basil Blackwell. 1975) particularly 169, 172 [hereinafter, Scanlon, "Ravis" "Thear"]; Vinit Haksar, Equalin; Libern: and Perfectionism (Oxford: Oxford University Press, 1973) thereinafter Halksar, Purfectionism); Joseph Raz, The Moraling of Freedom (Oxford: Charendon Press, 1986) (hereinalter Raz, Morality of Freedom]; Will Kymlicka, "Rawls on Teleology and Deontology" (1987) 17 Phil. \& Publ. Affairs 167, 188 [hereinafter Kymlickn "RawIs on Teleology and Deontology"l: Jeremy Waldron, "Symposium: The Works of Joseph Raz: Autonomy and Perfectionism in Raz's Mondity of Freedom" (1989) 62 So. Cal. L. Rev. 1097 [hereinifter Waldron. "Autanomy and Perfectionism"]; Stephen Gardbaum, "Commentary: Why the Liberal State Can Promote Aloral Ideals After All" (1991) 104 Harv. I. Rev. 1350, 1353 [hereinafter Gardbaum, "Liberal State Can Promote Moral IdeaIs"I; Robert George, Making Men Moral: Civil Liberties and Public Moralin (Oxford: Clarendon Press, 1993) [hereinafter George, Making Mfen Moral]; George Sher, Beyand Neutrality: Perfecrionism and Politics (Oxford: Oxford University Press, 1997).

3. The mene identification of a theory as perfectionist is handly conclusive of the perfectionist nunure of a theory, and it is empty to ask whether all cfforts at the theoretical understanding of the relationship between morals and American law are perfectionist. Such efforts inform any understanding of the questions posed by perfectionist legal theories. There are, then, many writers 
In other words, legal perfectionism broadly enshrines the notion, sometime unpopular among Western theorists, that the government has, or should have, the power to reflect ideas of good and evil-me content of the good life or of good projects or of excellence-in framing the laws. ${ }^{+}$While related both to older ideas of human perfection and perfectibility and to perennial concepts of virtue and morality, legal perfectionism has developed a distinct, modern meaning.

Rawls framed the modern conception of legal perfectionism in A Theory of Justice. ${ }^{6}$ In order to give the players of his thought experiment a theoretical contrast to his theory of justice based on faimess, rights, and equality, ${ }^{7}$ Rawls presented

who have been lately concemed with whether law does or should promote conceptions of virtue, goodness, or excellence in the citizen or society, such as the ongoing work of Ronald Dworkin, operating mote or less within the construct of modem liberalism, and Michael Sundel, stunding more or less outside of it. See Ronald Dworkin, Taking Rights Seriously (London: Duckworth Press, 1987) [hereinatiter Dworkin, Taking Rights Seriously]; Ronald Dworkin. Freedom's Lav: The Moral Reading of the American Constitution (Cambridge, MA: Harvard University Press, 1996); Michael Sandel, Liberdism and the Limits of Jistice (Cambridge: Cambridge University Press, 1982); Michael Sandel, Democracy's Disconient (Cambridge, MA: Belknap Press, 1996).

The term "perfectionism" has a distinct application in American constitutional theory, to suggest that the U.S. Constitution should incorporate particular values of liberal community. See Henry P. Monaghan, "Our Perfect Constitution" (1981) 56 N.Y. U. L. Rev. 353; Frank I. Michelman, "Constancy to an Ideal Object" (1981) 56 N.Y. U. L. Rev. 406.

4. This defintion is taken, roughly, from Jeremy Waldron's interpretation of Raz's definitions. Sce Waldron, "Autonomy and Perfectionism," ibid. 1102. Such a broad definition is necessary in order to encompass most of the various articulations of perfectionism as a justification for laws, particularly the theoretical array of the ends of perfectionist law. To promote cultural excellence. to pursue virtue, to make likely the good life, to promote autonomy, to discourage depravity, and more, have all been proffered by legal theorists as the ends of perfectionism. Each end, if adopted as the sole end of a perfectionist jistification to the exclusion of other ends, would suggest a significantly different set of laws that would be justified.

5. The articulation of this modern meaning is the task performed in Steve Sheppard "The Concept of Legal Perfectionism" (manuscript on file with the author). There are earlier predicates to this modern idea of perfectionism, not the least being various forms of natural and divine law. See George, Making Men Moral, supra note 2 . Related concepts are often dealt with as questions of progress, as well as human perfection and perfectibility. See, e.g., J.L.Bury, The Idea of Progress: An Inquiry into its Origin and Growth (New York: Dover Press, 1987); Arthur O. Lovejoy, The Great Chain of Being (Cambridge, MA: Harvard University Press, 1936); John Passmore, The Perfectibility of Man (New York: Charles Sctibner's Sons, 1970), Martin Foss, The Idea of Perfection in the Western World (Princeton, NJ: Princeton University Press, 1946). These ideas continue to influence the culture of American law, not only regarding particular laws, such as the perfectionist belief in abolition as a predicate to salvation, but in providing more general content to the good life, such as perfectionist ideas of the soul. See Robert M. Cover, "The Supreme Cout, 1982 Term: Foreword: Nomos and Narrative" (1983) 97 Harv. L. Rev. 4; Michacl H. Shapiro, 'Fragmenting and Reassembling the World: Of Fying Squimels, Augmented Persons, and Other Monsters" (1990) 51 Ohio State L. J. 331.

6. (Cambridge, MA: Harvard University Press, 1971)[hereinafter Rawls, Theory of Justice]. Rawls drew his conception of perfectionism from earlier writers, although none used the term preciscly as Rawls does. See note 19 below. The doctrine as used in recent legal theory seems to be first discussed by Rawls. See Rawls, Theory of Justice, ibid. at 25. Jeremy Waldron likewise cammenced his consideration of Joseph Raz's use of the doctrine with mention of its origin in Rawls. Waldron, "Autonomy and Perfectionism," supra note 2 at 1102.

7. Famously, Rawls's thought experiment of the original position places ideally mational parties in a "veil of ignorance" so they may agree upon a social contract reflecting the basic principles of a just society without knowing their future talents or position. The rules selected in the experiment are the two principles of justice:

(1) Each person has the same claim to a fully adequate scheme of equal basic liberties, which scheme is compatible with the same scheme of liberties for all; and in this scheme 
opposing theories of justice and social order based on intuition ${ }^{\text {s }}$ and teleology.? RawIs presented two teleological theories ${ }^{\text {th }}$ classical utilitarianism $"$ and perfectionism ${ }^{12} \ldots$ rejecting each as less preferable than his theory of justice as faimess to the players in the original position. ${ }^{13}$

In this grand comparative process, Rawls's discussion of perfectionism both embodies several meanings of perfectionism and provides the foundation for the wealth of legal theory that has developed upon it. ${ }^{\text {L }}$ He described two different

the equal political liberties, and only those liberties, are to be guarantead their fair value. (2) Social and economic inequalities are to satisfy two conditions: first. they are to bs attached to positions and offices open to all under conditions of fair equality of opporturity; and second they are to be to the greatest benefit of the least advantaged members of society.

John Rawls, Political Liberalism 5+6, 291 (New Yod: Columbia University Press. 1993) [heteinafter Rawls, Political Liberalism]; Rawls, Theory of Justice, supra note 6 at 302 Rawls his reshaped his first principle as a result of Hart's criticiom of the claim of priority and then redinfted the second principle for harmony in the text. Rawls. Political Liberalism at Sn., citing H.L.A. Hart, "Rawls on Liberty and its Priority" (1973) 40 U. of Chicago L. Rev. 534.

8. Rawls defined his intuitionism as "the doctrine thal there is an imoducible family of first principles which have to be weighed against one another by asking ourselves which balance, in our considered judgment, is the most just." Ravls, Theong of Jistice, supra note 6 al 34 . According to Rawls, these first-order principles will sometimes lend to conflicting directives bzeause there is no inherent priority by which to choose between coniticting standiards. Thus, he notes that a characteristic of this doctrine is the unanalyzable nature of any distinction between the right and the good, Ibid., or between competing views of whit is just. Ibid. at $40-45$. However, the intaitionist specification of something as inherenty good (and thus to be pursued) is made indspendently of specifications of the content of the right. If the right is then delined as the maximization of the good, then the intuitive approach can be perfectionist. lbid. at 40 . Rawis did not refute intuitionism and even granted that it might be correct. Rather, he rejected intuitionism in favor of a theoretical altemative that be liked better. Ibid. at 39.

9. His definition of teleological-atat in such theories the good is defined individually from the right"-is stipulative. See Rawis, Theon of Justice, supra note 6 at 25.

10. Kymlicka criticized Rawls's description of perfectionism as teleologieal, particularly to contrast a deontological description. "Some perfictionists may well betieve that the good they prefer ought to be maximized.. . But there are also perfectionists ... who would find it unfair to sacrifice one person's pursuit of excellence just because doing so would increase the overall amount of excellepce in society. Kymlickn, "Rawls on Teleology and Deantology" stupra note 2 at 167 . On the other hand, Kymlicka's reconstruction simply rejects Rawis's stipulated definition of parfextionism, which intentionally does not account for Kymlickn's second, more egalitarian, form of perfectionist Under Rawis's strict perfectionism, a less successful person's pursuit of excellenee must be sacrificed to increase the ovemll amount of perfectionism. Cr. Seanlon. "Riwils" Theory" supra note 2 at 172 . The difference between Kymlickn's egalilurian perfectionism and Raw's's strict view is illustrated in the Goethe and Grisham example, infra in text accompanying note 23.

11. Rawls's consideration of classical ucilitarianism is rooted in the Benlhanite view offered by' Henry' Sidgwick of organizing society to produce the greatest satisifation among all individuals. Rawls, Theory of Justice, supra note 6 at $22, n .9$. Rawls rejected this form of social orter as insufficiently accounting for the distribution of benefits among persons, thus not taling their distinctions seriously. Ibid at 26,$27 ; 183+84$.

12. Rawls, Theory of Justice, supra note 6 at 22: 325 , et seq.

13. He apparently rejected întuitionisin as founded on a mistalke, thal there can be no prionity of goods. Rawls, Theory of Justice, supra note 6 at 40.45.

14. One commentator has rematied on the scant detail Rawls offers concerting his opposing thories. including perfectionism. "First, it is fair to say (is students in one of my seminurs observed) that Rawls has not developed a political conception for utilitarianism or for perfectionism to sct along. side his own political conception of justice." Rex Martin. Rawls's Nev Theory of Jusfice (1994) 9 Chicago-Kent L. Rev. 737, 749, n29. It is true that Rnwls's discussion of perfectionism is dispersed throughout his works, particulary in Theory of Justice. Moreover, Rawis did not concem himself with the details of perfectionism, particularly its application in a socicty, in anything like the degree he articulated the sociery he believed possible under the two principles. 
theories for realizing perfectionist ideals of justice in the structure and laws of society, labeling one as Nietzschean, the other as Aristotelian. ${ }^{15}$ His Nietzschean theory of strict perfectionism required society to be organized to produce the highest levels in society of excellence in human endeavors, so that the efforts of all people would be directed to support the efforts of a few truly great people. ${ }^{16}$ His Aristotelian. theory of weak perfectionism employed the development of such greatness as one of several intuitionally competing ends. ${ }^{17}$ Thus, the end of society under both of Rawls's views of perfectionism was the production of the highest forms of excellence in arts and sciences by the individuals most capable of such production in society. The distinction between strict and moderate perfectionism is essentially whether other social values will be balanced against the pursuit of cultural excellence. Beyond these two, expressly enunciated constructs of perfectionism, Rawls's theory illustrates a constructive approach to liberal tolerance as a form of perfectionism in keeping with his view of moderate perfectionism.

This article explores these three manifestations of perfectionism in Rawls's writings. Its three parts each collect Rawls's statements concerning one form of perfectionism, drawn from the corpus of his writings. Each part then considers his bases for rejecting these forms of perfectionism as a basis for a just state and then considers critical problems in these rejections. It is not intended that these problems refute Rawls's conclusions but offer limitations on their application. Each part then presents a brief view of the form of perfectionism, as it might be reconstructed to respond to his objections.

It is important to note that Rawls has, of course, amplified and modified his views over time, particularly as to the role of the good and of duties of the citizen in a fair political state, the mature result being largely encapsulated in Political Liberalism. Even so, Rawls's initial conceptions of perfectionism have formed the basis for much of the literature, and so his initial conceptions of perfectionism and its rejections are presented in the first two parts of this article with little more than foreshadowing of the changes that might have altered his initial analyzes had they then been applied. Rawls's mature approaches are treated here more fully in part three.

So part one considers strict perfectionism, and part two considers moderate perfectionism, both largely relying on Rawls's carly formulations of perfectionism and his theory of justice and fairness. Part three incorporates more of Rawls's later work and applies particularly the work of Thomas Nagel, James Griffin, and Ronald Dworkin. The article concludes by suggesting that a reconstructed form of moderate

15. Rawls's description of weak perfectionism as Aristotelian should not be confused with his nore famous "Aristotelian principle." Rawls described weak perfectiontism as Aristotelian bectusc it draws generally upon Greek examples of justification, particularly the claim that Athenim slavery was justified by Greek achievements in the arts and sciences. Rawls, Theory of Jistice, supra note 6 at 325 . The Aristotelian principle is tus articulation of a basic principle of motivation for the individual to tend to pursue a realization of the good, so that, "otber things equal, humen! beings enjoy the exercise of their realized capacities (their innate or trained abilities), and this cnjoyment increases the more the capacity is realized, or the greater its complexity." Ibid. at 426 .

16. Rawls, Theory of Justice, supra note 6 at 325.

17. Ibid. at 325-26. 
perfectionism is defensible as a basis for a just society, that many of Rawls's preferences for a just society are compatible with such a form of moderate perfectionism, and that Rawls's project may be seen as a particular form of moderate perfectionism, or liberal perfectionism.

\section{Part I. Rawls's Strict Perfectionism: Cultural Excellence as the Highest Social End}

\section{I.A. The Doctrine of Strict Perfectionism}

Rawls initially presented strict perfectionism as a dystopian conception worthy of the Brave New World; it was little more than a straw argument to be repudiated in the original position in favor of justice as faimess. ${ }^{18}$ In the strict form, perfectionism is the "sole principle of a teleological theory directing society to arrange institutions and to define the duties and obligations of individuals so as to maximize the achievements of buman excellence in art, science, and culture." According to this doctrine, the value of a person's life is measured by contribution to the good in the production of social resources to be consumed by the highest specimens of humanity, those capable of producing excellence in art, science, and culture. The measure of the success of society is the sum of the value of the lives of great humans, who are humans who do great things such as Socrates and Goethe:"

The crux of strict perfectionism is that society should be arranged solely to produce the highest of human achievements and excellence in someone, but not every-

18. The concentration of resources to produce excellence in culture and science, art and athletics, is a motif in Huxley's themes of Fordism and eugenic breding- See Aldous Huxley, Brave New: World (New York Harper and Row, 1971) at 25, et sta. Krislian Kuma discusses these images in the dystopian gente in Utopia \& Anri-Utopia in Modem Times (Oxford: Basil Blachicll, 1937) at 224 , et seq. Four decades after the stark images left by Huxley in 1932, it is a view designed to lose, and in the losing demonstrate why the twentieth-century liberal view is preferable. The link between Rawls's view of perfectionism and Huxley's book was suggested by Hakstr. although to make a different point. See Haksar, Perfectionism. supra note 2 at 172 . The ast of labeling a theory "peffectionism" wos, at least in the decade following $A$ Theory of Jurrice, secn as a means of discrediting that theory, a point itlustrated in the rather defensive note offered by Heary Monaghan that his use of the word really was descriptive and not "pcjorative" See Henry Monaghan, "Our Perfect Constitution" (1981) 56 N.Y.U. L. Rev. 353,358, n.35.

19. Rawls, Theory of Justice, supra note 6 at 325. Rawls reforred to Rashdall and Nietzsetrs as sources for this presentation of the argument. In a procursor to trickle-down economics, Rashdall angued for the allocation of greater resources to those "men who are more capable of good," the benafits of such an uneven distribution going indirectly to the less good of the same generation but uniformly and directly to all members of surceeding generations. Rashdall was more compelled by the latter argument, which reflect the benefits that modern Europe received from slave-supported Athens. Hastings Rashdall, 1 The hreory of Good and Evil (Oxford: Clarendon Press. 1907) at 241. Rawls looked to the aphorisms of Friedrich Nietzsche to support the simpler view of producing great men as the telos of socicty, with an essentially instrumental role for lesser people. This is an undoubtedly fair appraisal of a Nietzschean view of equal respact. Sce, e.g. Friedich Nietzsche, The Whll to Power Walter Kaufman, ed, (New York: Vintegc Books, Random House, 1968) at 125; Richard Schacht, Nietzsche (London: Routledge \& Kegan Puul, 1983) at 267.

20. Rawls, Titeory of Justice, supra note 6325. 
one. ${ }^{21}$ Rawls argued that this view is supported by a claim that, in such a perfectionist system, those who would have worked to promote the excellence of others should do so because the attainment of this excellence by a minority (a minority because success may require a concentration of rights or resources to attain such excellence) is a proper end of social order. This end can be so general as to amount to a comprehensive view of the good, which is so complete and systematically ordered that it may exclude other views of the good. ${ }^{22}$

As an illustration of the strict theory, one might posit a world in which John Grisham, an entertaining and justly popular American novelist without pretensions to cultural greatness whose literature does not raise the standards of culture, is a contemporary of Johann Wolfgang von Goethe, whose literature manifestly raises the cultural standards of the human race. According to Rawls's principle of strict perfectionism, Grisham's most just service would be not to perform his own writing, but to support Goethe or, at least, to contribute as best as he can to the social structure by which Goethe would produce great literature. Grisham's contribution may then be through the taxes on his book sales, which then have excellence not in themselves but as contributions to Goethe. ${ }^{23}$

The view of the individual in the society governed by perfectionism is therefore one similar to that Ronald Dworkin has described as having value according to the impact of one's life. ${ }^{2+}$ The ethical value of a single life in Rawls's strictly perfectionist state is measured entirely by the value of the consequences of that life in promoting greater cultural excellence in the world. ${ }^{25}$

\section{I.B. Rawls's Rejection of Strict Perfectionism}

In A Theory of Justice, Rawls examined his conception of strict perfectionism according to the methods of his famous thought experiment. He claimed to test, first, whether strict perfectionism might be adopted as a just basis of society by

21. There is a continuing question of what Rawls meant as "excellence" and "achicvement." His failure to answer this question is part of his argument to reject the doctrine. But from his descriptions of cultural, artistic, and scientific success, and of the claim to justify perfectionist society through the works of Goethe and Socrates, a rough conception can be formed.

One attribute of this rough conception is that it is a limited view of human perfection, the perfection of performance rather than personhood. Each of his examples cites excellence at one task (writing novels, performing scientific research, etc.) by an individual as the basis for a claim to excess resources. Excellence in performance alone, however, varies from Rashdall's approach of tying such claims to good character and from Nietzsche's conception of individual greatness, which is more akin to perfectibility.

22. See Rawls, Political Liberalism, supra note 7 196. Rawls defined his uses of comprehensive conceptions of the good in his work on the overlapping consensus. Ibid. at 154.

23. This illustration makes clear an essential understanding of Rawls's strict perfectionism, that certnin achievements of excellence in culture cannot or will not occur unless there is a diversion of the resources that would go to others in a fairer system to the producers of culture. See text accompanying infra note 55 .

24. Ronald Dworkin, "Foundations of Liberal Equality" in 11 The Tanner Lectures on Human Values 1, 55-57 Grethe B. Peterson, ed.» (Salt Lake City: University of Utah Press, 1990) [hercinafter Dworkin, Tanner Lectures].

25. This definition is narrowed from the scope in which Dworkin proposed it. He claimed merely that an impact model of ethics is based on "the value of its consequences for the rest of the world." $\mathrm{Ibid}$ at 55 . This formula allows those consequences to have value for more than just contributing to higher standards of culturai excellence, aithough such contributions would strely have impact. 
players in the original position and, second, whether institutions supporting the adopted principles of justice can allocate liberties or goods according to principles of perfectionism. ${ }^{35} \mathrm{He}$ determined that strict perfectionism is unsuitable for both tasks.

Strict perfectionism must have a method for "ranking different kinds of achievements and summing their values." ${ }^{\prime \prime}$ Such a method need not precisely define every assessment, but it "should be accurate enough to guide the main decisions concerning the basic structure." Rawls rejected the possibility that the ideal players can agree on such a method because their potential individually chosen conceptions of the good might conflict with the potential socialiy chosen forms of excellence. The players

\begin{abstract}
know that they have (or may have) certain moral and religious interests and other cultural ends which they cannot put in jeopardy. Moreover, they are assumed to be committed to different conceptions of the good and they think that they are entitled to press their claims on one another to further their separate aims. The garties do not share a conception of the good by reference to which the fruition of their powers or even the satisfaction of their desires can be evaluated. They do not have an agreed criterion of perfection that can be used as a principle for choosing between institutions. To acknowledge any such standard would be, in effect, to ateept a principle that might lead to a lesser religious or other liberty, if not to a loss of freedom altogether to advance many of one's spiritual ends. If the standard of excellence is reasonibly clear. the parties have no way of knowing that their claims may not fall before the higher social goal of maximizing perfection. Thus it seems that the only understanding that the persons in the original position can reach is that everyone should have the greatest liberty consistent with a similar liberty for others."
\end{abstract}

For such a controversy to take place in the original position, Rawls placed the forms of cultural excellence into manifestations of the good beyond his "thin theory" of the good. Acting only to pursue the thin conception of the good, the ideal players prefer certain primary goods regardless of other theories of the good, effectively, no more than "a wider to a narrower liberty and opportunity, and a greater rather than a smaller share of wealth and income." As a result, Rawls then placed

26. It may be beneficial for the reader less well-versed in Ravis's theory' to rememter thal "the players" is a metaphor for a single rational, jdeal party; there is no ral bargaining and no disigremem? in the original position because the players, or party, acts on a single seheme of rationality. Ruwls. Theory of Justice, supra note 6 at 139.

27. Rawls, Theory of Justice, sipra note 6 at 327.

28. Ibid.

29. Ibid. at 327-28 (emphasis supplied). In essence, Rawls stated that if the stanthard of cxeelience is given substance then the players will defend the activities and projects that would ba barred or inhibited by the adopted standard. What the players do not know is whether their preferences will fall outside that standard. This limitation applies Rnwls's answers to both the questions of why the players cannot deternine elemeats of excellence which would not bar projects that are rational according to the thin theory of the good and the question of why ail projects are given equal respect in the original position. Sec also infra note 42.

30. Bid at 396. The primary goods initially included goods that are secially defined-rights and liberties, powers and opporturities, means and wealth, and self-respect-and to the degree other goods are not defined by natural fimits-health, vigor, imaination and intelligence. bidl. al $62_{2}$ In the slightly expanded methodology Rawls has since adopted, primary goods includa specific and listed basic rights and liberties; freediom of movement and free choice of occupation; access to power and office; wealth and income; and the social bases of self-respect. Rawils, Political Liberalism, supra note 7 at 181 . 
certain forms of universal human attainment outside of the scope of the good that can be pursued in the original position. These non-primary goods cannot be pursued even if everyone might prefer that some of these excluded forms of human excellence might be attained, at least by someone, because no players can be assured of personally attaining such excellence following the lifting of the veil." This restlt is compatible with Rawls's notion of perfectionism as a social and not a personal attainment; he stipulated that the desire to attain a conception of personal or social excellence is not within the thin theory of the good. ${ }^{32}$

Although Rawls did not acknowledge a pure view of excellence that he wotld allow to be sought by the players, he did acknowledge a practical form that he considered unusable in the original position. Rawls admitted that "in ordinary life," there are comparisons of intrinsic worth, that works of art can be judged and that well-being and freedom can be compared between two individuals ${ }^{13}$ So the available standards to determine what is better than something else (the perfectionist standards) are not rejected as a principle of justice owing to impossibility or even to vagueness. They fail only because "in view of [the ideal parties'] disparate aims, the parties have no reason to adopt the principle of perfection given the conditions of the original position." 34

Rawis accepted that the players could agree on certain forms of excellence, if they were defined to agree on more articulated standards. If the players had been defined to possess a natural duty to pursue some form of human aesthetic or style or to advance the pursuit of knowledge or the growth of the arts, the players could have agreed on an ethic of perfectionism. ${ }^{35}$ Rawls has not suggested that humans do not have such duties; he has merely claimed that the players of his thought experiment are not defined to have them and that to give such duties to them would change his rules of the original position. ${ }^{36}$

So, by limiting his players from having natural duties, Rawls has ordained that his players must choose a system of fairness in access to liberties and resources in which the faimess in the distribution is based only upon receipt, not use of, the goods. Of course, Rawls's purpose in using idealized characters is to allow a principle of agreement in the distribution of primary goods that is based on an neoKantian sense of moral equality among all people, regardless of differences between them. Because natural duties, or conceptions of excellence, might not be desired

31. The "veil" is briefly discussed in stpra note 7 .

32. Ibid. at 328 .

33. Ibid. at 328 . He briefly argued that such standards are too imprecise for political reliance and so they cannot support political perfectionism. He offered no reason why such standards must be unsuccessful, other than that they would be "unsettled ind idiosyncratic in public, however reasonably they may be invoked within narrow traditions or communities of thought." Ihid. at 330 .

34. Ibid. at 328.

35. Rawls, Theory of Justice, stupra note 6 at 328 .

36. In order for the parties to adopt perfectionism, they would require "a prior acceptance of some natural duty, say the duty to develop human persons of a certain style and aesthetic grace, and to advance the pursuit of knowledge and cultivation of the arts. But this assumption would drastically alter the interpretation of the original position." lbid. at 328 . Rawls is not, of course, opposed to the idea that people have natural duties. Indecd, he claims that each person has natural duties to establish and to support just institutions. Ibid. at 334 . 
or pursued by every person, he excludes such duties or conceptions (by keeping them from the thin theory of the good) from the players' motivations in the original position.

In other words, Rawls's principle of justice as faimess in the distribution of social goods can be seen as one in which fairness, at least initially, is based on receipt of the goods, not on any conception of how the goods can or will be used. Players, once the veil is lifted, would then be utterly free to use the goods or liberties or, at least, to use them in any manner that does not violate the two principles. Most importantly, if this rejection of perfectionism is correct, the players have only a limited duty to use their goods or liberties for the benefit of any other, simply because they lack any duty, except for the two duties that flow from Ravls's principles: a duty by those with more material goods to use them to the benefit of those with less and a duty by all not to infringe on the liberties of others. The players after the veil is lifted need not suppose they will be required to use their liberties in order to prevent others from Iosing their liberties at the hands of third parties, if to do so would lead to a loss of their own liberties. They may, so long as goods are not given in excess to them, suppose they may waste goods. Thus, Rnwls's players reject perfectionism as the inevitable consequence of their definition. The players were initially created without a sense of duty or excellence, and so they cannot pursue a system of social organization that is organized to enforce duties or create acts from duty or of excellence.

In recent years, Rawls has expanded his notion of the role of the good in framing a conception of justice. He, now, generally suggests that notions of the good may be freely introduced as needed to complement the political conception of justice, so long as such notions are political notions of the good and unrelated to a single comprehensive view. ${ }^{37}$ This modification may now limit the force of his early rejection of strict perfectionism, particularly as Rawls has similarly accepted only a very narrow acceptance of neutrality to describe his project of political liberalism. "Even so, Rawls's initial characterization of perfectionism was rejected on the basis of the thin theory, and certain useful aspects of this contrast remain important to understanding Rawls's initial conceptions of perfectionism.

After discarding strict perfectionism as a basis for a theory of justice, Rawls further tejected perfectionism as a political principle of organization to be adopted in accordance with the selected theory of justice, arguing that it cannot be compatible with the two principles of justice the players selected. ${ }^{2}$ His idea of a perfectionist political principle would require the state's coencive apparatus to be used to give greater shares of resources or liberties to those engaged in projects of excellence, in order to make likely a higher production of these more intrinsically valuable projects. ${ }^{\circ}$ This he rejected as violating both the difference principle and the principle of right, unless the resources given to such projects are either "won as

37. Ravyls, Political Liberalism, supra nate 7 at 194.

38. See Rawls, Political Liberalism, supra note 7 at 190-201. This mare expansive rolte of the gocd is considered below in section III.

39. The principle of right (the first principle) and the difierence principle (the second principles are described in supra note 7.

40. Rawls, Theory of Justice, supra note 6 at 328-29. 
a fair return for services rendered" by those engaged in such projects or are made from the voluntary contributions of other citizens."

Specifically, Rawls argued that perfectionism is incompatible with the principle of right because he assumed that rights in a perfectionist state must be ordered so that intrinsic value, measured by the ability to contribute to the production of excellence in society, is maximized across all persons in society rather than in each person. Because individuals do not achieve equal excellence in their activities, he assumed that those who achieve greater excellence would have greater liberty and that such individuals having a greater intrinsic value would, therefore, have a basis for greater rights. ${ }^{42}$

He also maintained that perfectionism is incompatible with the difference principle because distributions of resources yield a higher net generation of social excellence when granted in excess to especially talented people. So Rawls claimed perfectionism cannot ensure that rights will be equally distributed. Perfectionism was rejected in the original position both because it provided "an insecure foun. dation for the equal liberties [principle]" and because "it would presumably depart widely from the difference principle." 43

In the end, the strength of Rawls's initial rejection of strict perfectionism rested on little more than a single assertion, that the players have no definition of excelIence. ${ }^{t 4}$ Lacking such a definition, Rawls determined that perfectionism is not an allowable mechanism to support the two principles. By so doing, he assumed that distribution of resources and even rights unequally to the more talented may give greater value to society. Implicitly, to reject a scheme that reflected such an assumption is to accept a state that gives less value to society. So the players seem to prefer a less valuable society simply because they cannot ascertain what would be valued. Beyond this near tautology, the players also prefer a less valuable society if it is more egalitarian."

41. Ibid. at 329 .

42. "[T]he criterion of perfection insists that rights in the basic structure be assigned so as to naximize the total of intrinsic value" among all persons. Rawls, Theory of Justice, supra note 6 at 329. Although he assigned such a valuative technique to perfectionist theory, Rawls rejected it for his own theory of justice. Ibid. at $\$ 77$.

43. Ibid. at 330. I ignore any logical effect of this statement on his own theory, which Rawls "locuted" between utilitarianism and perfectionism. $\mathrm{Ibid}$. at 327 .

44. This point of course, presupposes the more general strength of preferring Rawls ss theory as if it is underived. Even if excellence can be defined and we can all, or nearly all, agree on its contcnt, there is still a failure of fit between strict perfectionism and the two principles; the pursuit of a generally agreed form of excellence can lead to a loss of liberty for some for the simple reason they prefer to act contrary to such an excellence. And, the pursuit of a generally agreed form of excellence may consume resources that would have been available to the lesser off among those who reject the form. I an indebted to Kent Greenawalt for raising this point. Even so, the failure of fit is contingent upon the content of the definition of excelience being one that is opposed to the satisfaction of the two principles.

45. Lucas stands out in the crowd who criticize Rawls as unpersuasive in this result:

If I had been a Founding Father of the United States, I might well have voted for the Constitution on the grounds that, apart from its other merits, it provided a framework within which I could pursue my own happiness to the best of my ability. But if I had been persuaded by Rawls, I should have opted for some other system which gave me less freedom to rise or fall, on the grounds that for all I knew I might be congenitally unable to pursue my own happiness, and would fare less badly under a modern welfare state. If 1 


\section{I.C. Problems in the Rejection of Strict Perfectionism}

Four problems appear to limit Rawls's initial bases of rejection of strict perfectionism. The first is his rejection of a specific definition of what is excellent as being controversial. The second is his assumption that rights and resource allocations are unfair because perfectionism might concentrate rights and resources to benefit those who could produce culturally excellent outcomes. The third, and perhaps the most important to the development of a coherent depiction of legal perfectionism, is his incomplete account of the social nature, rather than the personal nature, of culturally excellent projects. The fourth, and the problem that most clearly highlights the limits of Rawls's initial theoretical foundation in the thought experiment as a basis for rejecting perfectionism, is his limitation of the parties from a conception of the good, a concern that is revisited in part III.

\section{I.C.I. Excellence and controversy:}

Rawls rejected strict perfectionism because his partial definition of cultural excellence is just sufficient to lead to conflict. By defining it so that any certain contingent meaning was left unascertained, players must reject it because their potential momal, religious, and cultural interests might be compromised by whatever conception of excellence would be adopted.

There are two apparent ways in which such a compromise could occur. Players may have tastes that they would be forbidden to fulfill because the stindard of excellence of culture in society forbids them; they would lose the right to exercise their tastes (the wrong religion argument). They may also be restricted in access to resources because the resources would be diverted to support the cultivation of excellence (the museums argument). ${ }^{\text {th }}$

The conclusion that perfectionism requires the loss of rights- the religion argument - is based on an incomplete description of the excellence to be perfected. Rawls claimed that the pursuit of some religions might be barred by the standard of excellence toward which society would be organized. But he did not demonstrate why "excellence" (once the veil is lifted) must either include projects that offend some religions or exclude projects that would be required by them. This is less a matter of reasoning than it is of Rawls's definitions. The players in the original position are defined to have no shared conception of the good that they could refer to for the comparison of their desires; only Rawls's definition banred the "everyday

were a born loser, I should want very difierent rules from those which would appeal to me if I were simply an ordinary man in the original position.

J.R. Lueas, On Jusfice (Oxford: Clarendon Pross, 1980) at 193-94 thereinafter Lueas, On Jistice].

46. The rejection of perfectionism on these two criteria can be seen by two potential rules that might have been supported by a perfectionist society, which would have been rejected by those players whose potential projects would have been inhibited: (1) A fund for the brightest mathematicians, which because of scarce resources would hate required a 5.5 diminution in the recources abailable to the rest. (2) A prohibition on lives dedicated to pushpin. According to the principles selected. however, the players might have atcepted perfectionist social structures requiring: (1) A similar fund for the advanced training of urban planners. (2) A probibition on lives dediented to murder. 
life" conceptions of excellence from being considered a matter of reason. ${ }^{43}$ Moreover, we are told that the players selected the difference principle from all possible resource distribution methods. The players could have likewise compared all possible conceptions of excellence and selected the least intrusive.

In this way, Rawls initially barred perfectionism because the religion argument allowed intolerant religions that would have pursued a single and exclusive comprehensive view of religious obligation and required the persecution of competing religions. ${ }^{+8}$ But there is no reason for the players to accept a conception of excellence that lacks toleration, and there is strong reason to suggest that toleration must be a component of any reasonable conception of excellence that incorporates an opportunity to pursue a conception of the divine. ${ }^{49}$ Toleration can be easily included as a necessary condition of a reasonable conception of excellence, one that responds to "everyday notions" of excellence. . $^{\circ}$

Rawls initially maintained, however, that such conceptions, even those that contain requirements of toleration, must still be rejected because they are controversial. Indeed, he cited an argument on this very point, the Hart-Devlin controversy, which essentially is an argument for or against tolerance, as a basis for rejecting moderate perfection. $^{\text {s1 }}$

There are several ways, however, in which such a selection of a view of excellence might be uncontroversial. ${ }^{52}$ Primarily, the selection can be based on a con-

47. Rawls defined the forms of the reason and knowledge with which he endowed the players, and he deliberately removed from them the conceptions of everyday valuation and excellence he conceded we all use. See Rawls, Theory of Justice, supra note 6 at 331. Thus the players must initially consider as possibly valid life plans that not only reject the right but also include murder. This argument, and others of incoherence of the behavior of the players, is well developed at Lucas, On Justice, supro note 45 at 192 , et seq. This is one of the many elements of the original position that are not universally persuasive.

48. Such religious intolerance is, obviously, an important datum in the history of Western religions. The archefype is the lnquisition. See Miroslav Hroch and Anna Skybová, Ecclesia Militars: The Inquisition, trans. Janet Fraser (Leipzig: Dorset Press, 1988) Rawls faces concerns for the religion argument in his clarification of justice as political and not metaphysical, in which he specifically illustrates his concems to exclude an intolerant comprehensive vicw with the conflicts between Catholics and Protestants in sixleenth-century Europe. Sce Rawls, Political Liberalism, supra note 7 at 148, citing Quentin Skinner, 2 The Foundations of Political Thought (Cambridge: Cambridge University Press, 1978), especially part III.

49. Indeed, as an historical matter arguments for toleration emerged in Europe precisely during the height of the sixteenth-century religious disputes. See Skinner, 2 ibid. 241-54. Toleration is, of course, an ancient and recurring philosophy whose influence waxes and wanes in westem culture. See the classic study of Hendrik van Loon. The Siory of Tolerance: The Story of Mar's Striggle for the Right to Think (New York: Liveright Publishing Co., 1927).

50. Indeed, toleration has become such a part of everyday notions of excellence, at least in some caltures, that Lord Scarmon began a 1983 speech on legal toleration with the phrase, "To a lawyer, in a sense, toleration is a non-subject. Toleration is, and has been for a hundred years or more, part and parcel of the English way of life." Lord Scamon, "Taleration and the Law" in Susan Meadus \& David Edwards, eds., On Toleration (Oxford: Oxford University Press, 1987) at 49.

51. Rawls, Theory of Justice, supra note 6 at 331, described infra note 71 .

52. Raz rejected Rawls's rejection of perfectionism because of its controversiality in the original position. "They are not more controversial nor more evaluative than some of the psychological facts available to the parties, such as the Aristotelian principle...." Raz, Morality of Freedom. supra note 2 at 127-28. Raz offered three reasons to refute Rawls's rejection of perfectionism in the original position: in the single culture to which Rawls's theory applies, there may be common conceptions of the good, and these conceptions, being in common, need not be excluded in the veil of ignorance; the modes of reasoning of the good may be agrecd upon; in which casc, we might agree to accept our second-best preferences, which is a method of compromise similar to the original position. Ibid. at 124-30. 
ception of human nature that is universal and immutable." One manner by which this can be accomplished, which is common in the Western tradition, is to rely on a very short list of attributes that are assuredly excellent.: Using a short list of attributes of excellence may not allow the robust but imprecise conception of excellence that Rawls contemplated, which is a single comprehensive vision capable of defining the excellent in the arts, the sciences, and the whole of cultural achievement. Rather, it is more likely that the conception of excellence that could be employed in the original position would resemble the thin theory of the good; it would be limited to such ideals as seem intrinsically to be pursued no matter what concept of excellence one holds." Such a conception of excellence is more than merely plausible; it would satisfy the conditions for selection of the original position. ${ }^{36}$ With the veil of ignorance lifted, the players would have no reason to fear that they or others would pursue such a conception of excellence and would desire that they and others might pursue it.

One important manner by which such conceptions of the good may be found to be uncontroversial is to follow the lead of James Griffin in working backward from the moral notions already instantiated in the culture's legal and social apparatus. ${ }^{n}$ By looking to the uncontroversial norms that are to be found in the legal materials, such as "Don't deliberately kill the innocent," tools may be derived that are not only able to provide the context necessary to make specific claims of the good but also are able to select between competing views of the good."

Lastly, it must be suggested that controversy is not necessarily a reason to reject the pursuit of conceptions of excellence. Rawls suggests that the existence of controversy in a choice is reason to eschew the choice, at least if political judgment

53. This is the central approach to classical ideals of perfectionism. Its most powerful modern exposition is in Thomas Hurka, Perfectionism (New York: Oxford University Press, 1993).

54. This is a central part of the enterprise of most definitions of the good life, as it is in the construction of most ideas of natural law. While there are variations anong differing approaches to such selections, there is much more in common than there is distintt. Compare the appreach of Thomist approach of John Finnis to the more Humean view of James Griffin. John Finnis, Nartural Lasy and Natural Rights (Oxfond: Oxford University Press, 1980) at 59-99; James Griffin, Well-Being: Its Meaning, Measuremem and Moral Imporfante (Oxford: Oxford University Press, 1986) it 67-68; James Grifin, Value Judgement: Inproving Our Elhical Belicfs (Oxford: Oxford University Press, 1996) at 19-36. These modern approxches, in tum, follow more empirieal clairns of human satisfaction, such as Maslow's hierarchy. See Abroham Mnslow, Mforiation and Parsanaling (New Yotk: Harper, 1954) at 80-106.

55. The idea that we can amive at a theory of the good that is assuredly excellent is one based on an objectivist approach. Sher, Beyond Neutraliny supra note 2 at 176-198. One mechanism for assessing the good in an objectivist manner is presented in Gewith's subtle use of generic goods and generic rights. Alan Gewith, Reasons and Moraliny (Chicago: University of Chicago Press, 1978) at 48-103. Such an approach almost certainly riquires an ideal Ievel of knowledge in the actor expressing a choice. See Richard R. Brandh, Facts, Values, and Morality (Cambridge: Carmbridge University Press, 1996) at 12-60.

56. Moreover, as is suggested briefly below in pan III, there is a good argument to suggest that the two principles of justice that were selected may be described in this way.

57. James Griffin, "Moral Law, Positive 1,aw" in John Toulmin, ed, Lew, Vather, and Social Proctices (Aldershot, UK: Dartmouth Press, 1997) at 39-58.

58. For these purposes, it is unnecessary to expand Grifin's proposition to assert that certiin ideas are universal for all legal systems and thus are artifats suggesting universal goods. Rawls's theory is culturally contingent, and the boundaries here of Rawis's culture and Griffin's legal systems are roughly similar. 
is to be made, because the ideal players' views of excellence might not win the controversy. However, a society without controversy, at least some forms of controversy over what is excellent in the arts and culture, would be a very dull society and not necessarily to be preferred by the ideal players. Certainly as a matter of history in the arts, culture, and science, such controversy has been necessary for progress toward new forms of excellences, because over time winners lose and losers win in the aesthetic debate. Within limits (such as non-violent forms of expression) controversy is necessary to reach a decision regarding the contents of excellence, and the participation in such controversies might be preferred by the players, even if they believe their preferences will not be selected as the preferences to be culturally pursued..$^{59}$

\section{I.C.2. Concentrations of Rights and Resources and the Individual.}

There is a second problem in Rawls's initial rejection of strict perfectionism, an unsupported assumption that perfectionism would favor one class of people over another class. ${ }^{\circ}$ This claim of favoritism is based on Rawls's view of natural talents, one of the personal attributes shorn from the players by the veil of ignoratnce. It leads Rawls to present both resource allocation and rights allocations as favoring those with a capacity for excellence to the detriment of the rest. In many cases, however, the designation of people with such capacities must be initially open to all, since exclusion would eliminate individuals who possibly could develop their talents to a level of excellence. It is unclear that the players would reject perfectionism if they knew either that the opportunity to compete would be equally available to all or that excellence could be attained in at least some fields by the development or exercise of an unexceptional personal capacity of natural talents. ${ }^{61}$ Indeed, without an opportunity for individuals to be identified for such roles, either through competition or other methods that allow challenge to the current holders of such roles, historical progress is unlikely to be possible, and the limits of excellence could not be extended. ${ }^{62}$ As such an extension is necessary to maximize the value of cultural excellence, perfectionism would seem to require some criterion of change in the individuals who hold roles as producers in each field of excellence.

Thus, universal access to develop particular talents is necessary to allow the development of some important forms of excellence. If so, then one of Rawls's suppositions in rejecting perfectionism, that a concentration of rights or liberties

59. I have in mind here some of the writings of Rosalyn Krause and Robert Hughes. A fine cxarnple of this point is provided in the Brustein's theatre criticism, in which mainstream acceptance is a death knell for art. Robert Brustein, Dumbocracy in America: Studies in the Theatre of Guith, 1987-1994 (Chicago: Ivan R. Dee, 1994).

60. The nature of such an assumption, especially a constructive assignment of this assumption to Rawis's theory, must account for whether the class meribership is immutable or open to cliss mobility. Given Rawls's view of natural talents, it seems fairest to characterize his vicw of these classes as largely immutable, subject only to the development of artificial talents of some form or to the failure to develop or exercise natural talents.

61. One way to clarify this problem is to imply to RawIs a limited conception of excellence that is closed to the creation of new forms of excellence, but this clarification seems extreme.

62. Progress is here used in the historical sense described by Bury and Lovejoy. Sec supra note 5. 
would be necessary in order to promote excellence in society, may be false. A concentration of a particular liberty in order to produce a particular form of excellence would, if the liberty is necessary to produce the excellence, forbid universal access to prepare or to produce that same excellence.

That said, there is a certain, linited, strength to Rawls's objection to perfectionism of greater resource allocations to the producers of excellence, given the faimess of Rawis's stipulation of scarcity in resource availability. Regardless of those universal talents in which an opportunity to develop them makes them democratic, there must remain those natural talents in which there are some who are initially gifted in an extreme will perform better in the area of these talents than someone less gifted but more diligent, and these people may, in a perfectionist society, have a greater claim on resources.

In this sense, in a perfectionist society a great piano teacher might have time available to teach but one student, and the teacher would be required to provide that time to the young prodigy and not to the young plodder. If we assume that there is really only one great teacher, that no teacher could have taught the plodder as well as the great teacher, and that both students would have advanced at a similar rate in the time available but differ only in their starting positions (all rather dubious factual assertions), then the plodder is denied a resource solely because of a lack of talent. Rawls would thus suggest that the players would select some manner by which each can compete for the lessons without regard to who would receive them, such as a Iottery or a queue, rather than a manner that ordains the plodder to lose, because one of the players could end up being the plodder when the veil is lifted.

This diversion of resources rests on another important understanding of Rawls's strict perfectionism, that certain achievements of excellence in culture cannot or will not occur unless there is a diversion to the producers of culture of the resources that would go to others in a fairer system. There mny be historical grounds for such a view, based on the architectural and artistic triumphs produced during times of extreme atistocratic or bureaucratic patronage made possible by great inequity of resources. It is far from certain that such an imbalance of resources is necessary to promote such triumphs or similar triumphs in the future. The examples of great art produced by the poor, such as the works of Vincent van Gogh and Socrates," indicate that the empirical basis to suggest that Rawls's diversion is necessary for strict perfectionism is not proved. Rawls acknowledges this possibility, and his rejection is based not on its impossibility but on its lack of certainty.t

Furthermore, there is a tremendously strong argument that state support of a form of excellence would limit the expressions of that excellence from the risks and trials necessary for the highest of attainments. It might be that the best the state of society can do to promote some artistic, cultural, or scientific achievements is just to stay out of the way.

Even so, the problem of the plodder pianist persists. Setting aside the empirical

63. Not to mention Diogenes.

64. See the text accompanying supra note 29. Riwls further rooted his rejection of outcomes that might be good or bad in his nefusal to allow the players to gamble, beesuse a poor gamble weuld jeopardize the claims of descendants. See Rawls. Theory of Justice, supra note 6 at 128. 
weaknesses of the example for its metaphorical strengths, it is still not certain that the players in the original position would not prefer to allow a resource allocation method that would take into account the qualitative differences of the use of the goods, so that the goods would be put to the use that would maximize cultural value. The ideal players conceiving themselves as the plodder would, in effect, trade away an improved (but still mundane) ability to play the piano for a significantly greater performance by the other players as prodigy than would be possible otherwise for either of them without such a trade. It is not clear that the ideal players would not accept a less wonderful skill level in return for the opportunity to hear a superlative performance by someone else. ${ }^{65}$

\section{C.3. Social or Personal Engagements in Excellence.}

A third, and perhaps the most telling, weakness in Rawls's initial rationale for rejecting strict perfectionism is implied in his concern for resource diversion to the producers of excellence: the achievement of social excellence is a personal project of the producer of the achievement and not a social project of all of the people in society. This view is based on the selfish, personal view by players in the original position: if the players in a perfectionist state might be required to surrender some liberties or resources to the producers of excellence, the players are assumed to desire not to do so and to lack a natural duty to do so. ${ }^{56}$ In light of Rawls's later writings, this view is no longer certain to be that of the ideal players in the original position.

Why should we presume the approach of the players of the original position to be selfish, merely desiring as much of the pie as possible, regardless of how the

65. David Norton criticized the difference principle and its selection over perfectionism on related grounds. He argued that some people would have a stronger clain, and desire, for certain goods (such as Zubin Mehta for a metronome and Mario Andretti for a race car). So, the proportion of goods held by each is the measure between persons, and the justice of this allocation is assessed by merit. This test of justice is best seen in the guestion of the person with less, "Is the holder of more goods than me worthy of doing so?" This test suggests the difference principle is unable to reflect distinctions in the qualitative identities of citizens, an unsurprising outcome under the veil of ignorance. Moreover, the difference principle is based on a deliberntely limited, and so flawed, description of human ability. Genius and excellence are not well described by a natural lottery. They are more the product of the human will. "We are now ready to say with confidence that the real execptionality of genius lies in matters of tenacity, courage, self-discipline, willingness to sacrifice for a single objective- qualities which are by no means esoteric but availnble to all." Norton, "A 'Perfectionist' Rejoinder," supra note 2 at 56.

66. There is a fine line in Rawls's arguments here that should be observed. Rawls rejected strict perfectionism under the first principle because it might require the pursuit of projects that are conlrary to the player's view of excellence. This argument recognizes that the players have a scrse of cultural ends that entitle a claim upon others for success. Rawls, Theory of Jistice, stipra note 6 at 327 . Rawls rejected strict perfectionism under the second principle, the poitt of considerition above in this text, because the players fear risking resources and freedom that might be diverted to others in the pursuit of excellent projects. Ibid. at 327-29. This rejection is predicated upon the absence of a natural duty, which would allow for the subordination of one's desires for resources, rewards, and liberties (such as salary, fame, and opportunity) in response to others' claims upon them to pursuc cultural success, Ibid. at 328-29.

67. He has characterized his initial descriptions of the theory of justice as part of a theory of rational decision as incorrect, and the theory as a whole is better understood as an account of a reisonable principles of justice that is based on an intuitive theory of rational decision. Rawls, Political Liberalism, supra note 7 at $53 \mathrm{n}$. 
pie is then to be used? Rawls has himself rejected such a view as unreasonable, even though he continues to assert it as a component of the rational. ${ }^{\circ 7}$ Rawls asserts the players of the original position act only according to a rational desire for the greatest access to primary goods, but he asserts further that this, deliberately artificial, conception of the good is insufficient to support political conduct, and so justice as faimess also requires a reasonable pursuit of the political virtues of fair social cooperation. ${ }^{65}$ Thus, if political judgment cannot be rationally but unreasonably selfish, it might also be true that rationality may require a sense of understanding of -...and value of - the consumption of primary goods by others.?

Considering a paradigmatic project of excellence in the light of this selfish view of the rational, such as the U.S. N.A.S.A. manned space-flight program, suggests that this required selfishness might not be a required characterization of a rational decision-maker. The ideal player in the original position might consider that lifting the veil of ignorance and becoming Neil Armstrong (the first human on the Moon), Christie McAulfie (the schoolteacher who died in the Challenger disaster), a ground crewman, a taxpayer, or a welfare recipient who receives less assistance because of the budgetary diversion. Assuming that Neil Amnstrong is the producer most identified with the project, it is not clear that the ideal players might not prefer to see this form of excellence, accepting the chance that after the veil is lifted, the players would have any of the other relations to the project. Even the welfare recipient might prefer to forgo the dollar or two of monthly assistance for the knowledge that humankind, in which he participates, had reached beyond the planet. ${ }^{5}$ Indeed, civic participation in numerous forms of cultural excellence, such as sport, arts, architecture, and science may have as proprietary a sense for vicarious producers, consumers, or mere by-standers, as for the most essential producers."

68. Rawls, Political Liberalism, supra note 7 at 48-54 and 190-206.

69. Rawis is, of course, basing his mature use of the rational as opposed to the reasonable on the Kantian notion of rational people as lacking any form of socially conceised morals, but being merely predisposed to humanity and animality. Rawls, Politicol Libcralism. supra note 7 at SIn. The problem we face is that even such an amoral rationality may pursue a greater benefit to the self, a greater degree of bumanity in the thin sense, lhat purcly selfish motivations can admit. This is the reverse of the paradox of altruismi whether one can truly' act for the benefil of another without concomitant benefits to the sense one has of oneself.

70. This is not to say that any example of cultural excellence can be uninimously preferted, any more than it can be said that any person's exercise of liberty would be prefered by' others. Pablo Picasso, no mean producer of a different genre of projeets of cultural excellenee, dismissed the Apollo XI moon landing with, "It means nothing to me, ... I don't care"." Quoted in Jane Stems \& Michael Sterns, Encyclopedia of Pop Cuthure (New York: Harper Collins, 1987) at 28. The failure of unanimity regarding such projects of generally agreed cultural excellence may add strength to Rawls's view that the nature of excellence is controversial. Still, the essential nature of excellence is no more prone to controversy because of controversy at the margins than the essential nature of liberty is controversial because of difficulty in ascernining its ultimate limits.

71. Buddhist scholar Ronald Burr suggests an affinity between this Western iden of civic participation and a siguificant element of the Buddhist view of the role of the individual in a just society. The three most important obligations of the individual are to toke refuge in the Buddha, to take refuge in the dharma and to take refuge in the sangha. Refuge in the sangha is a form of religious obligation to venerate the monks of the Buddhist temples, especially by giving them alms. This iden of refuge in the sangha gives even the person who could neser be a monk the chanes to participate in the greater enlightenment of the monk This participation by one person in the enlightenment of another seems to distinguish the sense of refuge in the dhama from some Christian ideas of almsgiving, which are otherwise quite similar. Robent Nozick suggests a phenomenon concerning sports fans that is similar to dharma. and he describes its implieations for equality and liberty. Robert Nozick, Anarchy, State and Utopia (New York: Basic Books, 1974) at I61-64. 


\section{I.C.4. The Good and the Original Position.}

Rawls's early use of the original position gained wide acceptance for an idea of a system of society that is based upon selections by players employing the thin theory of the good. Even so, Rawls himself has recognized that the motivation of these players is so artificial as to "approach being psychopathic when their interests are solely in benefits to themselves."

The model of rationally ideal players who act on a theory of the good to allocate resources that are regardless of their use must be seen in a light that segregates the rational from the reasonable, so that only the rational is in play in the original position. The thought-experiment players in the original position, who are so clearly limited from the reasonable, are not as likely to be persuasive to the reader as a model either in selecting a system of social order or in rejecting other alternatives for social organization.

Rawls recognizes the additional requirement of reasonableness in supporting the society based on political liberalism. In doing so, it must be less certain that an intuitive reflection of competing systems can reject a particular system, if the rejection likewise does not include some form of reasonableness in the comparative intuitive process. Thus, it would seem that some idea of natural duties to cooperate must be allowed for any potential comprehensive theory of justice, including perfectionism.

This problem was revisited in Rawls's important later examination of the relationship of justice as faimess to comprehensive conceptions of the good, a consideration addressed in section III, below. ${ }^{73}$ Even so, his considerations have not been directed to the specific mechanisms of the use of a thin theory of the good in this manner but to the mechanism of overlapping consensus. While the idea of the overlapping consensus must be seen as an important new articulation of a foundation for justice as fairness, it does not amount in itself to a rejection of the thin theory of the good as a definition of the motivation of the players in the original position, and thus it does not, in itself, alter the role of the good in Rawls's rejection of strict perfectionism by that means.

The failure to include the reasonable within this narrow construct of rationality in the original position leads, then, to Rawls's initial definition of strict perfectionism as including such harsh social organizations as slavery, ${ }^{7+}$ leading then to its rejection in the original position. However, slavery is neither necessary nor unnecessary to the idea of strict perfectionism but is a contingent manifestation of its most minimal definition. A more robust definition of perfectionism can be distinguished into some forms that recognize slavery, which should be reasonably rejected on this ground, and into other forms that do not require slavery, which can be further considered for suitability. Rawls's moderate form of perfectionism incorporates an element of such a robust definition, moderated to allow for the rejection of

72. Rawls, Political Liberalism, supra note 7 at 51.

73. This is his consideration of the prionity of right and the ideas of the good, Rawls, Political Liberalism, supra note 7 at $195+201$.

74. Rawls, Theory of Justice, sispra note 6 at 325 . 
perfectionist forms of society that ought to be rejected for such unnoderated pursuit of social excellence as to allow slavery or other pemicious forms of social order.

\section{I.C.5. A Reconstructed Strict Raw/sian Perfectionism.}

Taking Rawls's initial premises of the nature of strict perfectionism and reconstructing them to account for the four critical problems raised above yields a new model of perfectionism. It is admittedly not the model of perfectionism Rawls sought to employ, and the differences between it and Ravls's preferred theory of justice are not so stark as to so usefully illustrate his theory.

The fundamental notion must remain to organize society in order to make likely the production of the highest achievements of excellence in art, science, and culture. However, the forms of exceilence of art, science, and culture that are to be pursued should be forms that minimize the degree to which controversy diminishes the legitinacy of the pursuit; the pursuit should not be one that alters liberties or rights; it should be valued not only across society but also in the individual; and the ideas of the excellence that can be pursued in a just society must be based on ideas of excellence that are rough and incomplete but that restrict excellence from unreasonable social structures.

\section{Part II. Rawls's Moderate Perfectionism: Cultural Excellence as One Social End}

\section{II.A. The Doctrine of Moderate Perfectionism}

Rawls's conception of moderate perfectionism limits the degree to which society is organized to pursue the same ends of cultural excellence sought by strict perfectionism. In this fonn, strict perfectionism is not the sole measure of society but is accepted as "but one standard among several in an intuitionist theory."' The moderate doctrine may apply both to highly perfectionist social theories, such as the Rashdallian defense of Athenian slavery (the loss of the slaves' liberty is justified by the gains made by leisurely thinkers), and to less wholly perfectionist theories, such as a modern defense of a constitutional limit on the redistribution of income (the "counterpoise to egalitarian ideas" is justified by the social contributions of more extravagant consumers). ${ }^{36}$

Moderate perfectionism is a more subtle amalgam of social ends that may simultancously require the pursuit of liberty and equality and of excellence and virtue. Such an amalgam requires occasional limits on the satisfaction of any single end

75. This form allows greater and lesser degrees of perfectionism according to the weight given to the "claims of excellence and cuiture." Rawls, Theon' of Justice, supra note 6 at 325 . Although in this formulation of the doctrine, Rawls boils down "exceilence in science, ant, and culture" into "excellence and culture," there is no other reason to assunie that the claim in the weakened form abandons scientists or artists as categories of valid users of periectionistically confentrated resources.

76. Ibid. at $325-26$. 
in order relatively to maximize satisfaction in each of the chosen ends. ${ }^{n}$

In both the strict and moderate forms, the need to preserve cultural values requires the diversion of primary goods to producers of excellence that might otherwise directly go to improve the lives of the worst-off citizens. At least in the moderate form, this may be done merely by setting aside a minimum amount of social resources to advance the needs of the people best suited to projects of excellence. It is not so certain that the moderate form requires the diversion of liberties along with physical resources.

\section{II.B. Rawls's Rejection of Moderate Perfectionism.}

Rawls considered the moderate form of perfectionism to be "much more plausible, and ... not easy to argue against." "is Even so, the failings that plagued strict perfectionism echo when it is intuitionistically moderated. Rawls found no acceptable basis for perfectionism as a standard of social justice, even if it is balanced with other considerations. ${ }^{79}$

RawIs had still defined the standards of excellence to be imprecise, making them difficult to employ as political principles. Despite their usefulness in narrow, everyday traditions and communities of thought, they would yield idiosyncratic and unsettled solutions to questions in the original position. ${ }^{50}$ This indefinite resolution to ideal questions is why the two principles would require any restriction of conduct to be based on a showing of an obligation or natural duty not to engage in that conduct, because

it is when arguments to this conclusion fail that individuals are tempted to appeal to perfectionist criteria in an ad hoc manner. When it is said, for example, that certain kinds of sexural relationships are degrading and shameful, and should be prohibited on this basis, if only for the sake of the individuals in question irrespective of their wishes, it is often because a reasonable case cannot be made in terms of the principles of justice. Instead we fall back on notions of excellence. ${ }^{\text {s" }}$

77. Rawls adopted Brian Barry's use of the indifference curve to illustrate a comparative exercise of maximizing the most critical ends until all are relatively satisfied. Rawls, Theory of Justice, supra note 6 at 37, citing Briun Barry, Political Argument (New York: Humanities Press, 1965) at 3-8 [hereinafter Barry, Political Argument].

78. Rawls, Theory of Justice, supra note 6 at 330 . Again here, his conclusion is based on agreement witl the two principles, not comparison to them. While this conclusion would further suggest consideration of moderate perfectionism as a principle for institutions, he concludes the same paragraph, on the next page, in the rejection of perfectionism as a conception of "social justice." lbid. at 331 .

79. Ibid. at 331-32.

80. Ibid. at 33I. This is a powerful argument, which presaged the thrust of his 1987 Hart Lecture, that arguments concerning political structure, made without reference to more geneml principles of good, are the basis for agreement among groups in a plural land. This he called overlapping consensus, which is to be pursued in order to make judgments that are the least controversial. See John Rawls, "The Idea of an Overlapping Consensus" (1987) 7 Oxford J. of Lcgal Stud. 1; and see also, John Rawls, "Priority of Right and Iteas of the Good" (1988) 17 Phil. \& Publ. Affairs 251; Rawls, Political Liberalism stipra note 7, lectures IV and V.

81. Rawls, Theory of Justice, supra note 6 at 331 . Rawis offers no reason why resort to ad hoc chims of excellence should be the sum of arguments based on perfectionism, or why perfectionism could not have been a natural duty other than that he has defined it not to be so. This language of natural duty is strikingly reminiscent of natural law justiffcations, widely accepted in the last century. 
But such determinations, in the world once the veil of ignorance is lifted, will be influenced by class, race, and personal aesthetics, which may be irreconcilable between citizens. ${ }^{82}$

In other words, peffectionist obligations-obligations based on excellence-..-are still controversial. ${ }^{83}$ The players would reject the moderate form, both as a basis of social justice and as a form of institution, because of the attribute of controversy."

Rawls also suggested, apart from his general consideration of perfectionism, that perfectionism would be rejected because it leads to envy among the less fortunate. ${ }^{\mathrm{s}} \mathrm{He}$ argued that the less fortunate would prefer the difference principle because they would then have no cause to feel inferior for receiving a lesser share, or at least they would feel less inferior than in other forms of polity, because these people would less resent an unfavorable imbalance of resources if they knew the imbalance benefitted them.

\section{II.C. Problems in the Rejection of Moderate Perfectionism}

The same essential problems attending Rawls's rejection of perfectionism in its strict form affect his rejection of it in its moderate form, but there are some subtler problems that arise more obviously in this context. Particularly, several results of Rawls's selected social organization are sufficiently similar to an intuitionistically perfectionist state that the similarity might suggest that Rawls was even more unconvinced than he claimed by his rejection of moderate perfectionism.

Rawls's acceptance of some social institutions that appear compatible with an approach intuitionistically balancing perfectionist ends with other ends of social justice is most apparent in his discussion of the exchange branch. In rejecting the

of sodomy laws. These are the subject of Rawls's following example not undor a clain of natural duty but of excellence.

Most importantly, this objection presents the claim that such arguments are ad hoc as if that alone is damning. This is integral to Rawls's theoretical approach. Yet there are numerous counterarguments, notably those derived from the writings of Blaise Pascal. See, eg.. Albart Jonsen \& Stephen Toulmin, The Abuse of Casuism: A Histony of Moral Reasoning (Berlisley: University of California Press, 1988).

82. Rawls, Theory of Justice, stipra note 6 at 331.

83. "Since these uncertainties plague perfectionist criteria and jeopandize individual liberty, it seems best to rely eatirely on the principles of justice whith have a more delinite structure." Rawis cites the mere existence of disagreement between Professor Hart and Lard Devlin over the sodomy laws as sufficient to avoid the whole issue. Ibid. at 331, n.54, citing H.L.A. Hart, Lon: Liberty, and Morality (Stanford, CA: Stanford University Press, 1963); Patrick Davlin, The Enforcement of Morals (Oxford University Press, 1965). It may be that Rawls is employing a concem for controversy similar to that of Professor Dworkin, who at one time escherved basing libeml political principles in controversial claims of humban nntere, lest the claims appeas tater to be folse, dimirishing the legitimacy of political liberalism. See Dworkin, Taking Rights Seriously, supra note 3 at 272

84. Rawls, Theory of Justice, supra note 6 at 331 . However, controversy is only the negative reason for the rejection of perfectionism. Rawls also claimed the players would prefer the two principles, a positive reason for rejection. This contrast is deseloped by Seanlon. Scanlon. "Rawis" Thandy:" supra note 3 at 169. Vinit Haksar discussed Rawls's use of controversy in justifying limits on paternalism and contrasts this approach to John Stuan Mill's. Hatesar, Perfactionism. stupra note 7 at 236 , et seq.

85. Ravls, Theon' of Justice, supra note 6 at 536 .

86. Ibid at 536 . 
strict doctrine, Rawls did not bar individuals from forming organizations or pooling their resources to advance science, art, or culture. ${ }^{67}$ So social uses of perfectionism would be permitted to justify non-statist but corporate acts, even though perfectionism could not be a political principle to justify any act of the state..$^{83}$

This dichotomy is, however, not fully consistent with Rawls's claim that his contractual terms would allow for public funding of the arts and sciences. He allowed this funding through the idea of the consent-based exchange branch. This branch of the government could be capable of making government expenditures regardless of the difference principle to benefit social interests and the public good, by requiring expenditures to be selected according to a principle of unanimity. ${ }^{89}$ Rawls left unexamined why such a device is better in a state agency than a private corporation. Indeed, one is tempted to suggest that, the essential difference between a state and a corporation being the power to coerce, the purpose of locating such an agency in the state is because consensus will be less than wholly unanimous, and some degree of perfectionist coercion might be useful. ${ }^{\circ}$

The principles of justice and of unanimous selection are paramount in the exchange branch, however, and Rawls particularly limited his exchange branch by barring any claim of an activity's intrinsic value as culture from being a basis under the principles of justice to support "subsidizing universities and institutes, or opera and the theatre." Taxes for such subsidies could only be taken from those who would not directly benefit from them if taxes would promote the "social conditions that secure the equal liberties and ... the long-term interests of the least advantaged."92 There is no reason, however, why this same condition cannot have been asserted as a limit on perfectionist employments of resources, particularly if the long-term interests of the least advantaged would eventually include consumption of such resources.

87. Ibid. at 328-29.

88. Ibid at 329 . Of course, this ojchotomy between a corporate institution and a governmental institution must be predicated on a rejection of many forms of the consent theory of goverment, accepting a more Lockean than a Hobbesian view. See Emest Barker, "Introduction" in The Social Contract vii, $\mathrm{xx}-\mathrm{xxi}$ (Oxford: Oxford University Press, 1947). This may seem a tad irotic in a contractarian model of the state, such as Rawls's. Yet it is the attempt to reconcile consent theory with a deontologic content of such consent that apparently drives Rawls's mission.

89. Rawls's method of managing the exchange branch is intriguing, a "representative body taking note of various social interests and their preferences for social goods." (It is unclear whether he means "social interests" as groups of like-minded individuals or as activities promoted by the whole. The use of "their" would seem to favor the first reading.) They may authorize expenditures for government activities independent of what justice requires, after satisfying Wicksell's илаnimity principle: no activity can be created unless its means of funding are also agreed on, nearly unanimously. Rawls, Theory of Justice, supra note 6 at 282-84, citing Knut Wicksal, "Finanztheoretische Untersuchungen" reprinted and translated in "A New Principle of Just Taxation", Musgrave and Peacock, eds., Classics in the Theory of Public Finance 72 (London: Macmillan, 1958). Rawls recognized some of the nearly insurmountable obstacles to such a creation (but still neglected the vast expense of a sujtable voting mechanism). He just left stcll problens aside. See Rawls, Theory of Justice, supra note 6 at 283.

90. Recalling Picasso's disregard of the first landing of man on the moon, described in supra note 70 , one must consider whether such a mild degree of, perhaps self-serving, rejection shoukd have precluded the funding of the Apollo project. Much of Rawls's project is to protect the ability of citizens to make such choices and so have such results.

91. Rawls, Theory of Justice, supra note 6 at 332.

92. Ibid. at 332. 
The problem of the controversiality of the form of excellence to be pursued is even more problematic in the rejection of moderate perfectionism then it was in the rejection of strict perfectionism. In this case, not only can perfectionism be limited to forms of excellence that are objectively pursued, but also these forms of perfectionism can be further limited so as to minimize conflict with other social goals. Thus, even if a form of excellence were selected that has an objectivist and universal appeal, it could not be pursued in society if it unduly conflicted with other, otherwise unrelated, social values. Thus, not only can the form of perfectionism considered in the original position be limited to a less comprehensive form in which everyone would agree that the form of excellence is worthy of pursuit, but even the manner of its pursuit can be limited by an intuitionist balancing with other social ends. In this way, a universally acceptable form of excellence, such as "people should be encouraged to engage in conduct that maximizes their potential for exercising their talents," must be militated by other important social values, such as "conserve resources for the poor," and "ensure the privacy of the individual."

It remains uncertain that players in the original position, contemplating being among the worst off, might not prefer a project that would keep some degree of resources from them but still prefer it for perfectionist reasons. Such choices could be seen to promote the primary good of self-satisfaction, because the identification of oneself with a saint feels ennobling."2 In this way, such choices vould merely swap distribution of one type of resource for another, both of which would go to the group with the least of each resource." When this is understood by the least off to be the case, and it is admittedly not always to be so, the problem of envy is likely to be moot.

Rawls, at least regarding choices based on perfectionism, has foreclosed this move because these choices must be made based on claims of excellence he rejected. All that remains is the severe requirement of near-unanimous approval for the exchange branch to allow a perfectionist choice." We are left then with a rejection of perfectionism, but with an allowance for a very similar but unatainable

93. Certainly, in the American experiedce this has been so. The public foundation of parts and monuments in U.S. cities to honor the work and ideals of Martin Lulhar King has baen supported by many, some of whom were very poor but saw his example as one to be promoted. In these cases, the benefit of excellence in culture was believed by the worst off to be worth diverting a small portion of tax revenues from social programs that might othervise have helped them better meet their basic needs. While there are cynical responses-that such promotion is desigrad by black civic leaders to encourage guilt among vealthy white citizens and thus stimulate grealer diversion of resources to poor black citizens or that such promotion was not to the decriment of social programs but to the detriment of lower ax rates - such responses still seem insuficient to explain the whole of this particular political movement, farticularly its support anong the poor.

94. This idea, that people in fact have such reactions, is an empirical hypothesis but one for which no statistical data is offered. Even so, as an assertion, Rawis, recognized interchanges batween the security of one type of primary good for andher as an eleruent of preticality. This recognition is elaboratod in his essay "Social Unity and Primary Goods" in Amarty Sen \& Bernad Willinms, Utilitarianism and Beyond (Cambridge: Combridge Unisersity Press, 1982). There is a separate question as to whether self-respect and subsidy to buy food are subject to the first and second principles respectively, a condition which would fore to be accounted for in factoring commenstarability. See Thomas Pogge, Realizing Rarts 122, ct seq. Ituszo, NY: Comsll University Press, 1989).

95. Rawls, Theory of Justice, supra note 6 at $282-83 ; 331$. 
result, an intuitionistically balanced method of supporting projects of cultural excellence that every single citizen agrees are worthy of support.

Certainly, some forms of moderate perfectionism would be unsuitable to the players in the thought experiment. Even so, it remains possible that some forms of perfectionism could be chosen, so long as a few obvious problems in definition are resolved. One form that certainly might be chosen within the moderated intuitive structure is the reconstructed view of strict perfectionism described above.

\section{Part III. The Perfectionism of Rawls's Theory}

The discussion in parts one and two of this article considered, primarily, Rawls's early contribution to the literature of perfectionism, in which he developed an important notion of perfectionism in order to reject it. Rawls remains perceived, perhaps wrongly, as a central advocate not only for the rejection of perfectionism but also for the defense of the doctrine of the state that is the converse of perfec. tionism, liberal neutrality, the prohibition of state enforcement of views of excellence or of the good. ${ }^{\%}$ This part presents arguments for Rawis's apparent neutrality and his limited acceptance of the label for his work, as well as some perfectionist dimensions that are reflected in his theory despite that neutrality. ${ }^{97}$

\section{III.A. Rawls's Limited Neutrality}

Neutrality is a label first applied to Rawls's theory by others, even if his theory reflects only a limited form of it. While not claiming that his theory was neutral in $A$ Theory of Justice, it is unsurprising that he has since adopted a circumscribed form of neutrality. ${ }^{44}$

96. Stephen Gardbaum provides an overview of the apparent contrast between legal perfectionism and political neutrality. See Gardbaum, "Liberal State Can Promote Moral Ideals," stipra note 2.

97. This article is not, by any means, the first to suggest that cffective maintenance of a fair liberal state, even a tolerant plural state very much like Rawis has suggested, will be somewhat perfectionist. Sunstein has suggested that, to ensure such pluralism and tolerance persist, controls are necessary to cultivate divergent conceptions of the good and to cnsure a degree of reflection on those conceptions. One might describe a system that took this goal seriously as embodying a mild form of liberal perfectionism. Such a system would see the inculcation of critical and disparate attitudes toward prevailing conceptions of the good as part of the framework of a Iiberal republic. Liberal education is of course the priscipal locus of this concern.

Cass R. Sunstein, "Symposium on Classical Philosophy and the American Constitutional Order: Republicanism and the Preference Problem" (1990) 66 Chicago-Kent L. Rev, 181, 194. See also Pogge, Realizing Rawls, stipra note 94.

98. Nagel seems to have been first to characterize Rawls's project as neutral. See Thomas Nagel, "Rawls on Justice" (1973) 82 Phil. Rev. 220, reprinted in Norman Daniels, ed., Reading Rawls 1, 8 (Oxford: Basil Blackwell, 1975) [hereinafter, Nagel, "Rawls on Justice"]. Raz scems to be the first to characterize Rawls as "anti-perfectionist." Raz, Morality of Freedom, supra note 2 at 117-33.

Rawls discussed his neutrality in John Rawls, "The Priority of the Right and Iteas of the Good" (1988) 17 Philosophy and Public Affairs 251, 260, et seq. [hereinafter, Rawis, "Priority of the Right"] This discussion was presaged by his arguments on the exclusion of ideals in the original position in his Columbia Dewey Lectures. John Rawls, "Kantian Construetivism in Moral Theory" (1980) $71 \mathrm{~J}$. of Phil. 515 at 545 , et seq. 
Prior to Rawls's own description of his neutrality, Thomas Nagel argued that. although Rawls's theory is based on neutral premises, the theory itself cannot be truly neutral because the conditions necessary for the parties to reach an agreement can only be justified according to a conception of the good. "It is one of those cases in which there is no neutrality to be had because neutrality needs as much justification as any other position." "No9 Nagel argued that the prohibition of the players' ability to value goods subjectively does not treat the parties equally. ${ }^{20}$ From this, Nagel concluded that Rawls's theory was based on a conception "according to which the best that can be wished for someone is the unimpeded pursuit of his own path, provided it does not interfere with the rights of others." "iit He argued that conceptions requiring valuable resources, such as those of expensive tastes, are less likely to be satisfied by the scheme adopted by the players. if Rawls discriminated against these conceptions, a discrimination he justiffed by claiming they are unfair. ${ }^{52}$ Thus, Nagel presented a form of discriminatory neutrality, in which the state cannot limit choices of the good among a set of choices that it bas already limited.

Rawls has accepted the label of neutrality only within a narrow form. He first claimed his interest is in the political concern of the state-mot in the exclusion

99. Nagel, "Rawls on Justice," supra note 98 at 9. A similar approach was taken by Haksar, Perfecrionism, supra note 3 at 288-97, and by David Nonton. See supra note 65 .

100. Nagel did not clarify why this incquality results, nor did Raz, who accepted Nagel's point. although Raz noted that the players who defend expensive tastes must persuade others to coopcrate in the satisfaction of his desires. See Raz, Mforaliny of Fretdom, supra note 2 at 120 . One method by which the veil produces inequality is based an the result onee the veil is lifted. Conceptions of the good which are dependent on more scarce resources may be insufficienlly defended because the likelihood is more remote that players will have this conectption. Thus, playess who bold these views are hampered in the bangaining process in protecting his ultimate goals. But players with a conseption of the good that is statistically more likely, because it ratzuires more commonly consumed resourtes, will be mote likely to pursue a social structure which matches his conception.

101. Nagel, "Rawls on Justice," supra note 98 at 10. In his examination of this passage, Raz emphasized that Rawls's conception of the good need not apply only to the life of the individual but may be conceptions for people generally of for sociely as a whole. Raz, Moraliny of Freedom, supra note 2 at 119. James Griffin has buile a powerful angument from this point. Sce James Griffin, Well Being, supra note 54; James Griffin, "On a Govemment's Favouring One View of a Good Life Over Others" lecture, Oxford University Sub-Faculty of Philosophy, Trinity Term 1990. (On file with the author)) (Parts of the methodology of this paper are developed in James Griffin, Value Judgement: Improving Our Ehical Beliefs, supra 54.

102. Nagel's was one of several arguments made, broadly, in this way: Rawls appears neutral. Neutrality means a number of things. Rawls rejected many of these things. Thus, either Rawils is not really neutral or Rawls offers no real reasons to supporn neutrality. Raz in Moraliny of Freedom, and Kymlicka, in Individuatism and Neutraliny, may be seen in this light. Rux, Moraling of Freedom, supra note 2; Will Kymlicka, "Individualism and Nettrality" (1986) 99 Ethics 883 [hereinafter Kymlicka, "Individualism and Neutrality"].

103. See John RawIs, "Social Unity and Primary Goods" in Amarty Sen \& Bemard Williarms, cds. supra note 94 at 168; John Rawls, "Fairness to Goodness" (1975) 84 Fhil. Rev. 553. Other conceptions that may be barred include those relying on community participation. See Adina Schwartz, "Moral Neutrality and Primary Goods" (1973) 83 Ethies 302 Raw's"s aceeptance of neutrality was followed by a flood of related criticism, particularly by communitarians. Sec, e.garguments collected in Amy Gutmann, "Communitarian Critics of Liberalism" (1985) 14 Philosophy and Public Affairs 308; Kukathis \& Petit, Ren\&ls: A Theony of Justice and its Critics (Cambridge: Polity Press, 1990), ch. 6. Kymlicka ofered a compromise view of community participation as a value for certain groups in Liberalism, Community and Culture iOxford: Chrendon Press, 1989). 
of ideals. ${ }^{104}$

[1]nstitutions and policies are neutral in the sense that they can be endorsed by citizens generally as within the scope of a public political conception. Thus, neutrality might mean, for example, (1) that the state is to ensure for all citizens equal opportunity to advance any conception of the good they frecly affirm; (2) that the state is not to do anything intended to favor or promote any particular comprehensive doctrine rather than another, or to give any greater assistance to those who pursue it; (3) that the state is not to do anything that makes it more likely that individuals will accept any particular conception rather than another unless steps are taken to cancel, or to compensate for, the effects of policies that do this. ${ }^{105}$

Rawls rejected forms (1) and (3). He claimed that the first form is excluded because it violates the priority of the right over the good; the limits of justice allow only permissible goods to be pursued. ${ }^{106}$ The third form could not be pursued compatibly with the two principles of justice; any attempts to redress the imbalance between favored and disfavored comprehensive views of the good would be futile. ${ }^{109}$ Rawls argued that only the second form describes his approach, so long as no comprehensive view of the good is favored. ${ }^{108}$ This limited form of neutrality fits with Rawls's picture of his theory as one that is political and not metaphysical. ${ }^{10 \%}$

\section{III.B. The Pursuit of the Good Through Overlapping Consensus.}

Rawls has made an important turn in defining a method for making controversial decisions necessary to the political framework by suggesting a framework of overlapping consensus that recognizes the inevitability of controversy in various contexts and aims to contain it without harm to the political fabric of the state. It is this framework that permits him to develop a reasonable model of the state that may pursue forms of the good but still not be perfectionist, when perfectionism is limited from his new definition.

104. Raz divided neutrality into separate forms to add clarity to the operation of the doctrinc, not necessarily to attribute certain elements to one form of neutrality or to exclude other elements of the other to any one writer. Kymlicka suggested that Raz wrongly labsled Rawls's neutrality as primarily that of neutral political concern. Kymlicka is correct in that this is not possible in the futlest extent, since Rawls bars some consequences demanded by total application of neutral political concern. Kymlickn, "Individualism and Neutrality," stupra note 102 at 884-86. But Raz was aware of Rawls's qualifications. See Raz, Morality of Freedom, supra note 2 at 119 . Further, Raz was careful to note that many of the points made concerning one version of neutrality apply to the other. Ibid. at 109 .

105. Rawls, "The Priority of Right," supra note 98 (emphasis ndded); ct. Rawls, Political Liberalism, supra note 7 192-94. Rawls initially drew the three divisions from Raz's construction of political neutrality. Raz, Morality of Freedom, supra note 2 at 114-15. Rawls claims that form (2) represents Dworkjn's version of neutrality. Sec Ronald Dworkin, A Matter of Principle (Oxford: Clarendon Press, 1986) at 191.

106. Rawls, "The Priotity of the Right," supro note 98; Rawls, Political Liberalism, stupra note 7 192" 95.

107. Ibid. at 262, 26468; Rawl\$, Political Liberalism, supra note 7 192-95.

108. Rawls, Political Liberalism, supra note 7 at 193.

109. Rawls's characterization of this limited neutrality is described by Cohen-Almagor as a "đutulified neutrality of aim, which "holds that the role of government is to secure equal opportunity for citizens to pursue any permissible conceptions of the good. By "permissible" is meant conceptions which appreciate the accepted principles of justice." Raphael Cohen-Almagor, "Bctwecn Neutrality and Peffectionism" (1994) 7:2 Can. J. of L. and Juris. 217 at 222. 
Political liberalism is not meant to describe or enshrine a metaphysical or religious view of the person, only a political one. ${ }^{10}$ The content of rules that are reasonably political is determined through a method of "overlapping consensus," to derive a single view by which adherents of different philosophical vievs of the person can agree on a political system. This framework is to be based on a conception of justice that (1) all publicly acknowledge as accepted, (2) is integral to the main political and social institutions, and (3) is based on a sense of justice that individuals actually believe and that enables them to understand it and to apply it." In order to pursue such a consensus, Rawls assumes that a reasonable approach to judgments for others must include a recognition of the opposing comprehensive views of philosophy, religion, or life held by others in a plural society. While it is not unreasonable to affirm only one of many competing comprehensive views, it is unreasonable to use political power to enforce one's affinmed view to repress other, not unreasonable, comprehensive views. ${ }^{12}$ The values that Rawls expects to be supported by overlapping consensus are similar to those that he expects are basic to the structure of justice, values of political and civil liberty, fair equality of opportunity, economic reciprocity, the social bases for mutual respect between citizens, and public reason as a basis for decision in essential choices of governance. ${ }^{\text {"13 }}$ Despite allowing the state and society to pursue such ends, which could be considered projects of excellence, Rawls can maintain that his state is not perfectionist because these views are not based necessarily upon a metaphysical comprehensive view. ${ }^{14}$

Nonetheless, Rawls concedes that a state that both reflects a political conception of justice and builds an overlapping consensus will inevitably limit individual conceptions of the good. Constraints on some individuals' activity are practically certain to occur, because the constraints are derived from the requirements of political

110. These points are made in many of RiwLs's later writings, but minly in "Justice as Faimess, Political not Metaphysical" (1985) 14 Phil \& Publ. Affairs 245, ct seq. which formed the basis for his discussion of "public reasons." Rawis, Political Libcralism, supra note 7, lecture VI.

111. This theory is developed in John Rawls, "The Idea of an Overnpping Consensus" (1982) 7 Oxford J. of Legal Stud. 1; Rawls, Political Liberalism, supra note 7, lecture IV. The relationshyp between the doctrine of overlapping consensus and the conception of a political dostrine is discussed in his "Domain of the Political and Overlapping Consensus" (1989) 64 N.Y.U. L. Rev, 233; Raw's, Political Liberalism, supra note 7, lectures III and IV.

As a matter of practical politics, Ravls would be overoptimistic in this tast. Some groups will be emotionally capable of surrendering some clains, which oppose cther graups' chims to participate, in a consensus that would abridge such claims. Some of these claims can be described as illegitimate for one reason or another. The claim of mafiosi to "insurance" from Brotklyn builders or of Nazis to legal discrimination against non-"Aryan" races can be casily rejected as unjust or irrational. But others are not necessarily unjust or imational, such as a Marxist claim to abolish the ownership of land. The prosecution of each of these claims requires the loss of some interest by others, interests they are likely strongly to desire to protect. Compromise of these interests according to acceptance of some more abstract principles is unlikely by atvocates of either side of any of the three claims just mentioned. The abstmet clnim for consensus could not be agreed upon because the casuistic result would cause rejection of the premise. As a representation of the ideal in a pluralist democracy, however, Rawls's viesv is still tremendously useful.

112. This amplification of the method of public selection of the content of the overiopping consensus is in lecture II of Rawls, Political Liberalism, supra note 7.

113. Ibid at 139. Public reason, which is a democratic prineiple of decision-making, is described in ibid. at $212-54$.

114. Ibid. at 194. 
justice for the basic structure, ${ }^{115}$ and the ways of life associated with these comprehensive views either directly conflict with the principles of justice or fail to gain adherents in a just political regime. ${ }^{166}$ Rawls recognizes this and has asserted that the pursuit of the goals of political liberalism may require the state to "affirm the superiority of certain forms of moral character and encourage certain moral virtues." 17 So, applying the principles of Rawls's theory, certain church rituals may be constrained to conform to the principle of toleration; university admissions may be govemed to maintain fair equality of opportunity, and the rights of parents are to be checked by "what is necessary to maintain their children's well-being and to assure the adequate development of their intellectual and moral powers." constraints on individual conduct must be taken as evidence of what is good, not only what is right.

Indeed, Rawls has incorporated the good of political society as a goal to be pursued by the politically liberal state. According to this good as an end of political liberalism to be pursued by the state, the state must pursue certain, non-metaphysical constructions of public virtue. ${ }^{119}$ Thus, Rawls recognizes that the achievement of a well-ordered society in which there are reasonably just, albeit imperfect, liberal and democratic institutions is an achievement of great social good. "That there should be such a political and social good is no more mysterious than that members of an orchestra, or players of a team, or even both teams in a game, should take pleasure and a certain (proper) pride in a good performance, or in a good game, one that they will want to remember."'20

\section{III.C. The Perfectionisms of Political Liberalism}

By limiting his rejection of perfectionism to a rejection of perfectionism to promote excellences based on a comprehensive view, Rawls has taken what now

115. In this, Rawls follows the views of Sir Isaiah Berlin, who argued that it is impossible for all of the possible goods of soctety to be simultaneously and equally pursued. Isaiah Berlin, "The Pursuit of the Ideal" in The Crooked Timber of Humanity (New York: Knopf, 1991) at 13.

116. Rawls, Political Liberalism, supra note 7 at $197 \mathrm{n}$.

117. Rawls, Political Liberalism, supra note 7 at 196. Rawls, Political Liberalism, supra note 7 at 194. This is the form that Raz's perfectionism takes, in that he asserts perfectionist laws, at least non-coercive perfectionist laws, are necessary in order to provide citizens with the opportunity to practice autonomy.

118. Rawls, "Justice as Faimess," supra note 110 at 245 n.27; sce also Rawls, Political Liberalism, sipra note 7 at 196-200; lecture VII. This last example is a fascinating example of Rawls's view of morality. The parcnts' duty under the social structure includes inculcating their child with moral powers. Whether such powers cun exist without a particular content is problematic, but when taken as a social constraint, such a duty suggests an obligation to train the child to participate in the liberal community.

119. According to these virtues, political liberalism is compatible with classical republicanism, understood as an encouragement of the moral power of citizens to participate in the protection of their liberties through political participation. Rawls, Political Liberalism, supra note 7 at 205-06. Rawls contrasts this non-metaphysical good of republican participation with an idea of civic humanism, in which political participation is seen as an end in itself, a vicw Rawls rejects. Ibid. at 204-06. Interestingly, RawIs makes a similar contrast with the comprehensive liberalism he describes in Raz's Morality of Freedom, which he agrees has some resemblance to political liberalism, with his rejection the cultivation of distinct virtues of a comprehensive liberal viev, such as atonomy, which is the central justification for the perfectionism Raz believes is necessary to the harms principle. Rawls, ibid. at 200; Raz, ibid at 407-29.

120. Rawls, ibid. at 204 . 
appears to be a less robust stand for anti-perfectionism than he appeared to hold in 1971. He has remained committed to some forms of limiting the legal designation of the good: no comprehensive religious, moral, or social theory ought to be enshrined as law. But this is not to say that the state may not properly condemn some forms of conduct as against the good required in a just, politically liberal state.

Within the framework of Rawls's fuller views of political liberalism, there are several ways in which his project is within the constructs of perfectionism that he first employed, which were discussed in parts I and II. Some ways of characterizing political liberalism are still within Rawls's more limited descriptions of perfectionism to promote a comprehensive metaphysical, and not a merely political, view.

The application of a perfectionist label to Rawls's theories of justice that least disturbs his initial use of the terms is the simplest, and the one he has most expressly accepted: the creation of a just society is itseif a project of the highest cultural excellence. ${ }^{21}$ Both the theoretical enterprise that John Rawls launched and the practical enterprise of constructing a just society and state can be seen as projects of cultural excellence in the same vein as the drafting or enforcement of a Bill of Rights. That this task is politically perfectionist, whether or not the project can be a part of a metaphysical construct, does not remove it from the set of projects of cultural excellence. Thus, to enshrine notions of equal rights and the fair distribution of resources in the social or political order is to engage in a perfectionist tosk of the highest calling.

The next method is to assert a more personal realization of the form of excellence in the task of creating a just society. This form of excellence is not to be summed across society but is to be maximized in each individual."? This view of an excellence in society is that promoted by Ronald Dworkin as the basis for a state that enshrines liberal equality, ${ }^{12}$ and it is near to Rawls's descriptions of the sportsmen and musicians who take pleasure in their performances. ${ }^{32}$ It is, in other words, a model of individual excellence based upon challenge rather than impact, al though specified to some extent so that challenge includes a personal engagement in the project of participating in a just society. ${ }^{130}$

121. This formulation is resonant of Rawls's later description of this social good. Compare Rawls ibid. at $20-4$ with Rawls, "Prionity of Right," supra note 98 at 270-71. $1 \mathrm{am}$, however, indebted to Professor Hart for a much earlier insight in providing this formulation.

122. This is largely the task George has followed by sculpting a perfectionist theory political theory that is based upon the protection of civil liberties. George, Making. Men Moral, stpro note 2 at 189-229.

123. See Kymlicka, supra note 10.

124. Dworkin, Tarner Lectures, stpra note 24. Sec also Ronald Dworkin, "Libernl Comumuity" (1989) 77 Cal. L. Rev. 479.

125. Rawls, Political Liberalism, supra note 7 at 204 , quoted above.

126. Dworkin presents a broader model of the challegge basis of ethies as fulfilling the Aristatelian concept of the skilifuliy led life, which may inclurie many of the values of the impact model of life, but values a well-led life without reference to other ethieal values. Dworkin, Furner Lectures. supra note 24 at 57-58. The argument here is closer to that of Stephen Macedo's in asserting that public values of liberal constitutionalism entail "many ways of livigg as a liberal," which amount to a set of private liberal virtues. Stephen Mncedo, Liberal hirues: Citizenship, Iirtue. and Community in Liberal Constitutionalism (Oxford: Clarendon Press, 1990) at 245. et seq. 
Consider, then, the case of a society in which excellence is maximized in each individual, rather than in society as a whole regardless of each individual. So long as each person's conception of challenge includes the skill of being just, the degree to which an individual's actions promote justice is the degree to which they are excellent. Rawls arguably recognized this point in 1971, when he described the two principles of justice as "ideal-regarding." 127 He claimed that the good of the well-ordered society would reflect the ideal such that desires incompatible with the ideal have no value and are not part of the good. ${ }^{123}$ Further, he argued that conformity to the ideal requires people to pursue certain traits (such as a sense of justice). Rawls recognized that these claims resemble perfectionist attributes. ${ }^{129}$ Moreover, his mature understanding of the nature of justice requires that each person should have as an end the giving of one another mutual justice. ${ }^{130}$ Certainly, Rawls has recognized a conception of political virtue that is both personal and political. ${ }^{31}$ If one accepts the move that the actualization of such a political virtue is a necessary form of excellence that is not subject to compromise with other values, then one has accepted Rawls's work as one of perfectionism in a form only slightly moderated from strict perfectionism.

A third manner in which Rawls's theory may be seen to be perfectionist is by criticizing his refusal to consider a standard of human excellence as possibly known in the original position. Rawls's reliance on his refusal to invoke a prior standard

127. Theories that are "ideal-regarding" pursue a conception of what is objectively best. "Want-regarding" theories pursue what people subjectively regard as a want based on their self-interest. Brian Bany, Political Argument 39 cited in Rawls, Theory of Justice, supra note 6 at 326. Iteal-regarding theories insist some wants should be ranked as more deserving of fulfilment than otliers; want-regarding theories do not. Professor Barry later considered Rawls's use of "ideal-regarding." Brian Barty, The Liberal Theory of Ihstice: A Critical Examination of the Principal Doctrines in A Theory of Justice by John Rawls (Oxford: Clarendon Press, 1973) at 19, et seq. Ihercinafter Barry, Liberal Theory of Justice]. He argued that Raw]s's approach either is a slightly abstracted want-regarding theory or is perfectionist. Barry's claim that the two principles are want-regarding is based on the original position: the players are given only wants, and thus the two principles are based only on wants. $I b i d$. at 22 . If this is not so, the players must rely on a "full tlieory of the good," a reliance which Rawls rejected in developing the thin theory of the good for precisely this use. But Barry argued that Rawls's claim-..-a want should not be satisfied if it conflicts with a theory's distribution criteria-does not make Rawls's theory ideal-regarding: simply excluding the value of a want is not to rank it. Ibid. at 25 .

Rawls also claimed that the two principles "define an ideal of the person without invoking a prior standard of human excellence." Rawls, Theory of Justice, supra note 6 at 327. But Professor Barry convincingly argued, "if Rawls is correct in stating that the principles are idealregarding there is either an inconsistency in the system or the premises do 'invoke a prior standard of human excellence." Barry, Liberal Theory of Justice at 26.

Without reconsidering inconsistencies in Rawls's system, it is still possible that Barry mny be best answered by rejecting Rawls's assertion that he is not perfectionist. Rawls has continucd to assert that the separate formulation of the right and its priority over the good are critical to his theory. John Rawls, "The Priority of the Right," supra note 98; Rawls, Political Liberalism, lecture VIII. But once his theory is complete, it becomes for the reader a theory of both what is right and what is good.

128. Rawls, Theory of Justice, supra note 6 at 326-27. See ibid. at 453 for an elaboration of the wellordered society.

129. Rawls, Theory of Justice, supra note 6 at 327 .

130. Rawls, Political Liberalism, stipra note 7 at 208. Rawls asserted that the personal nature of the obligation to accord justice to others is a necessary part of his claim that his $A$ Theory of Jistice is complete.

131. Ibid. at 207+09; Rawls, Theory of Justice, stupra note 6 at 433, et seq. 
of human excellence is potentially misplaced. ${ }^{12}$ Rawls created a theory that encompasses the good and presents an ideal, presenting at least some form of standard for human excellence: the degree of conformity to that part of the ideal which describes the role of the individual. In this way, the project of $A$ Theory of Justice supports a Kantian social and political system with broad perfectionist attributes: a form of the individual good of political society is created as a goal of social excellence to be enshrined in the state's institutions which then encourage the individual to pursue that good. ${ }^{123}$ The good can be further detailed through definition supported by an overlapping consensus. ${ }^{134}$ Such an approach to the definition would minimize the degree to which controversy can limit the perceived legitimacy of the selected forms of the good.

There is of course, a risk of mistake in unnecessarily conflating these opposing aspects of neutrality and perfectionism in Rawls's work and, in so doing, of lessening the explanatory benefit of the mechanisms Rawls has created for elaborating and refining our collective sense of justice. The possibility of such a mistake is real; it is perfectly possible to read this article loosely to suggest that neutrality is always perfectionist, even though this is neither epistemologically nor ontologically a sound suggestion.

Instead, the suggestions made above are designed to lay a foundation from which one might build a construction from Rawls's views of perfectionism a new

132. One approach to blurring the distinction between the right and the good was made by Kymlickn. See Will Kymlicks, "Rasvls on Teleology and Deontology" (1988) I7 Phil. \& Publ. Afíirs 173. There are other approaches that could support the view that what Rawls defined as rights sometimes limits his defined version of good, as his good somctimes limits his right.

133. Rawls, Political Liberalism, supra note 7 at 201-06. It should be noted that this form of universalizable excellence within the person may conflict with Raw's's initial stated conception of tho role of excellence in defining the good. In fleshing out his notion of the good as confined of the right defined by the two principles, Rawls claimed that individuals would have lises that includi as many objectives as possible. Rawls, Theory of Jistice, supra note 6 at 413 . Furthar, motivation of individual action would reflect Rawls's "Aristotelian Principle," according to which citizens are attracted to using their talents in complex forms. /bid. at 424 , et seq. He illustrated the preference for greater complexity: if a person is equally skilled at checkers and chess, chess will be preferred as a more complicated garne involving more faculties of inteilect. This point seems to be empirically flawed or at least culturally contingent. Even so, Rowis claimed that a rational plan of life must satisfy the Aristotelian Principle. Ibid. at 440. Accordingly, an individunl can pursue a good of self-respect, marked by the csteem of others who are esterned by him.

This subjective conception of esteem led Ravls to claim that excellence is subjective. The well-ordered socicty must bawe sufficient communities and associations that everyone can find someone who will hold him in respect. This requirement is a manifestation of the rejection of perfectionism. Since the "absolute level of achievement is irtelerant," and "as citizens, we are to reject perfection as a political principle," there can be "democmcy in judging paople's aims." Ibid at 442. Rawls thus barred any claim that one approach to art, science, religion, or culture is superior to any other approach; no form of social union could be superior to any other. $/$ bid. at 527.

Rawls's approach was examined by Martha Nussbaum, who contrasted this version of self respect with the concept of shame. Martika Nussbaum, "Sharne Separateness, and Politieal Unity" in Amelie Ronty, ed., Essays on Aristotie's Ethics (Berkeley: University of Califorina, 1980) 394 at 397-404. Rawls, however, does not aecept suth a universalizable vicw. He claimed that the good does not necessarily reflect a sense of justice. "For our good depends upon the sorts of persons we are, the kind of wants and aspirntions we have and are capable of. It can cren happen that there are many who do not find a sense of justice for their good." These people may have to be locked up. Rawls, Theory of Justice, supra note 6 at 576.

134. Rawls, Political Liberalism, supra note 7 at 166-68. 
conception of perfectionism that is compatible with many of the procedural and teleological views of justice that Rawls prefers. One suggestion is merely to designate the pursuit of a just social order as an end of excellence in itself, thus establishing a perfectionist social order. The second is to limit the players' neutrality to recognize and require the pursuit of a reasonable and limited conception of social excellence in both society as a whole and in each individual. The third is to enshrine those forms of excellence that are chosen by a selection process that is neutral among competing views of the good and to allow their later pursuit by perfectionist means. According to this third suggestion, while the constitution of the original position may be neutral, the laws necessary to give effect to its results need not be. In this manner, desires for justice, for toleration, even for art, that are neutrally selected can be the basis for a perfectionist order for society.

\section{Summary: Rawlsian Perfectionisms}

John Rawls has presented at least three frameworks for a perfectionist state, two deliberately and one constructively. The two deliberately articulated frameworks promote the attainment of cultural excellence in society. These views, created to be definitionally laden both with problems of ambiguous definition and with probIems of the maximization of production, were rejected according to the Rawlsian. method of the original position. Even so, when considered as an idea in itself, a reconstructed form Rawls's strict theory balanced as moderate cultural perfectionism has much appeal.

With the addition of two considerations, Rawlsian moderate perfectionism also may describe the great contribution Rawls has made in articulating the good of a politically liberal theory of justice. If excellence can be both given definition by a method like overlapping consensus and given a moderated basis of maximization to incorporate both personal and social maximization, then the good of social justice can be placed within the set of pursuits of excellence. Moreover, that set of excellences could include numerous forms of arts, humanities, and sciences that would accord well with Rawls's initial description of the ends of perfectionism.

Rawls might object to these moves as undesirable, on at least two grounds. First, the function of definition in A Theory of Justice, performed by comparison to the harsh characterization of strict perfectionism, is lost. The reasons for defining perfectionism in such a way as to maximize excellence across society rather than in the individual are both to represent an historical school of thought and to serve as a counterpoint for Rawls's distinct theory. To merge the characteristics of Rawls's theory of strict perfectionism with other perfectionist theories may be counterproductive to the purpose of illustrating Rawls's preferred theory of political liberal justice.

The response to this first criticism is both theoretical and practical. From a theoretical standpoint, there is no reason not to consider the reasons by which the intuitive balancing necessary to the moderate theory might occur. A careful definition of excellence and a democratically limited method of maximization are as valid in this balancing process as others. From a practical standpoint, it might also be that RawIs is wrong to the extent he assumes either that maximization of excellence 
in society excludes maximization of excellence within each person or that excellence should not have a delineation that is more related to the reasonable.

The second ground on which Rawls might object to these moves in redefining his conception of perfectionism is pragmatic, based on a claim that people have, as a contingent matter of fact, views of excellence that are comprehensive and subject to controversy. It is probably not the case that one can reasonably isolate certain conceptions of excellence that are susceptible to practical reason, or even to articulation, from inarticulate or aesthetic considerntions that are part of a comprehensive view. Excellence cannot be pursued in society as a whole because it is too contingent on individual views formed in cultural ghettos; it takes on too many forms that are exclusive of one another, and so delegitimizing controversy is inescapable.

Yet this objection would be unconvincing. Certain conceptions of excellence are general and comprehensive, just as are some conceptions of the good. By pursuing only conceptions of the good that are the products of reason and overlapping consensus, Rawls has asserted that political virtues may be ascertained from the larger set of comprehensive views of the good. There is no apparent reason why these same techniques cannot be used to isolate the limited set of excellence that may be subject to political and social pursuit from the universe of comprehensive views of the excellent.

Whether one accepts the limited forms of perfectionism that Ravls deliberately set out in 1971, Rawls has made broad strokes on the perfectionist canvas. He introduced the word in its modern form to the Iexicon of legal and political theory. He tied the term to the idea that the pursuit of excellence could be a proper basis for social organization, even if the content of this excellence is controversial. He presented an image with which we are unlikely to have sympathy, one that could ordain both slavery and starved children on the museum steps, but he also showed the potential softening of the harshness of that image by balancing it with other social goals and human needs. He then argued for limitations on more general perfectionist views by accepting a limited form of anti-perfectionism: the state should not enshrine a single comprehensive view of the person and require individual conformity to it.

These contributions to the ideas of perfectionism are, however, incomplete without considering the obvious, that Rawls has also offered a conception of social justice that is itself capable of being enshrined as a perfectionist basis for a just society and state. Granted, Rawls is reluctant to stand on such a plinth, which is contrary to portions of his views both of the segregation of the right from the good and of the methods of justifying a civic virtue of toleration within a plural state. Even so, once the preliminary tasks of ascertaining a right social order are completed, as they would be in a society that accepted the tools of the principles of justice and the mechanism of overlapping consensus, then the value of giving justice with such a content can be fairly pursued by perfectionist means. This pursuit of justice may be, on occasion, moderated by recognizing other needs, such as defending a system of just government from revolution or extemal threat. It may also be moderated by balance with the promotion of other forms of excellences in the sciences and arts. It would remain a moderately perfectionist liberal state. 